\title{
Augmented Reality and Pedestrian Navigation through its implementation in m-learning and e-learning: Evaluation of an educational program in Chile
}

\author{
Jorge Joo-Nagata ${ }^{a}$, Fernando Martinez Abad ${ }^{\text {, José García-Bermejo Giner }}{ }^{\mathrm{c}}$, Francisco J. García- \\ Peñalvo \\ a GRIAL Group. University of Salamanca e Universidad Metropolitana de Ciencias de la Educación, \\ José Pedro Alessandri 774, Ñunoa, Santiago, Chile. jorge.joo@umce.cl \\ ${ }^{b}$ IUCE Group. University of Salamanca, Paseo de Canalejas, 169, CP 37008, Solís Building, 1a floor, \\ Salamanca, Spain.fma@usal.es \\ c Departamento de Informática y Automática, GRIAL Group. University of Salamanca, Plaza de los \\ Caídos, S/N CP 37008, Office 3017, Salamanca, Spain. \{coti, fgarcia\}@usal.es
}

\begin{abstract}
The implementation of Mobile Pedestrian Navigation and Augmented Reality in mobile learning contexts shows new forms of interaction when students are taught by means of learning activities in formal settings. This research presents the educational, quantitative, and qualitative evaluation of an Augmented Reality and Mobile Pedestrian Navigation app. The software was designed for mobile learning in an educational context, to evaluate its effectiveness when applied as a teaching tool, in comparison to similar tools such as those present in e-learning. A mixed-method analysis was used, with primary school students from Chile as subjects $(n=143)$. They were split into one control group and one experimental group. The control group worked in an e-learning environment, while the experimental group performed the activity as field work, making use of the app (m-learning). Students were evaluated pretest and posttest using an objective test to measure their level of learning. In parallel, a satisfaction survey was carried out concerning the use of these technologies, in addition to interviews with several students and teachers of the experimental group. Pretest-posttest results indicate that the experimental group outperformed the control group in their learning levels. The results of the interviews and the satisfaction survey show that these technologies, combined with fieldwork, increase the effectiveness of the teaching-learning processes. Further, they promote the interaction of students with contents for learning, and they improve students' performance in the educational process. The main goal is to provide a methodology for the analysis of an ad-hoc designed app. The app is intended to provide an m-learning process for subjects being taught about cultural heritage. The quantitative and qualitative results obtained show that it can be more effective than using similar technologies in e-1earning contexts.
\end{abstract}

Keywords

Authoring tools and methods

Media in education

Navigation

Evaluation methodologies

\section{Introduction}

The ever-growing use of ICT has produced a new scenario that is affecting one of the most important elements in the development of any society: comprehension, analysis and visualization of the territory. This new scenario of work with digital and computer media, ranges from the simple representation or modelling of spatial scenarios, to the possibility of generating and structuring places from new and complex data structures (Virtual Reality). This has become possible with the development of extremely powerful processing techniques and methodologies for graphical display.

These developments have not remained outside the field of education; rather, they have influenced education very strongly through the creation of new dissemination tools, and of new knowledge creation and learning structures. In particular, new ideas and lines of action have been implemented that are related to the various types of established technologies, such as Mobile Learning (m-learning) and Ubiquitous Learning (u-learning) (Crompton, Burke, Gregory, \& Gräbe, 2016; C. S. J. Huang, Yang, Chiang, \& Su, 
2016). These technologies make it possible to join different fields of knowledge, producing a confluence of these different types of issues, and generating a complementarity of contents, methods and objectives.

Techniques such as Augmented Reality (AR) have been under development in the last 25 years, in direct proportion to the increased capacities and types of hardware, and particularly with today's growing importance of mobile devices and applications (smartphones and tablets). Thus, it is possible to find interesting new features for users and software developers, enabling the creation of content related to AR activities. This scenario has seen a practical incorporation into various fields of knowledge, among which are education and heritage, where there have been important implementations of thematic content, creating a new way to display and disseminate information present in the territory. In parallel, another technology that has been strengthened by advances in mobile devices, has been Mobile Pedestrian Navigation (MPN) (Elhoushi, Georgy, Noureldin, \& Korenberg, 2016), which derives from the use of navigation assisted by digital systems and of map servers, which allows the implementation of different thematic contents with consequences on their educational implementation. Both technological elements have been incorporated in different educational activities ranging from contents about environment (Kamarainen et al., 2013), to heritage and history (Chang, Hou, Pan, Sung, \& Chang, 2015). However most of existing research is presented solely from a qualitative point of view through observations, interviews or observation groups, or from quantitative methodologies in experimental fields (Sommerauer \& Müller, 2014). The purpose of these types of research is to determine the effect of the tools in learning achievement. To contribute to research in this area, we have conducted this study to measure the effects of AR and MPN learning from an m-learning context, comparing the results of these tools in e-learning contexts and in formal education settings (classroom).

Thus, the general objective of the study is the design and evaluation of a mobile application linked to the MPN and the AR, and framed within a process of educational training with the inclusion of technology (e-learning as a control group and m-learning as an experimental group). This is done within a framework of territorial information on the relevant historical and cultural heritage of the city of Santiago de Chile. From this context, we make use of a quasi-experimental methodology that establishes the hypothesis that students achieve higher levels of content acquisition (learning) on heritage and its elements using tablets and in a context of fieldwork (m-learning), when compared to activities developed by means of traditional teaching e-learning conducted in the classroom through a desktop computer. The theoretical foundation for this hypothesis is based on the cognitive theory of multimedia learning (CTML) and of the development of spatial intelligence. We approach e-learning and m-learning through the implementation of AR, digital mapping and MPN as applied to contents concerning historical, architectural and geographical aspects.

This document is structured as follows: the theoretical context of AR and digital mapping is shown first, both in educational processes and in situations of m-learning and e-learning context. Later, the quasiexperimental design used is described, emphasizing the treatments applied, as well as the test applied to measure the contents and processes. The rest of the paper deals with the statistical analysis of the results obtained, and includes evidence of the degree of satisfaction of educational activities carried out by the students and teachers who participated in the experience, incorporating interviews which produced information on particular elements of the educational process related to the use of technology. The discussion section compares the results with similar research efforts by other authors, and finally concludes with a summary and a reflection on the scope of the investigation.

\section{Theoretical background}

M-learning as a method of learning is directly related to e-learning, although it belongs indeed to an independent typology, where teaching and learning processes have an electronic and technological context, provided with the dynamism or movement and portability offered by some devices (smartphones and tablets) with high processing performance and storage capacity for digital information (Sánchez Prieto, Olmos Migueláñez, \& García Peñalvo, 2013, 2016). Thus, m-learning would be a natural evolution of elearning, allowing to students and users to have a learning process through mobile technology. Within an everyday context, navigation and the use of spatial mental maps are part of the understanding of the world in a person's mind. Distances, locations and relationships in and within the territory become a part of a cognitive process and find a place in human thought itself. The resolution of these spatial problems by means of computers (digital cartography and MPN) requires the generation of a navigation structure, that is, a further characterization of a territorial model that allows us to understand the spatial reality of subjects (Gardner, 2006). These elements have already been employed in mapping and navigation systems, which since ancient times have tried to represent and communicate territorial scenarios. Nowadays, these systems make use of digital devices and provide us with real time information. All this is related to spatial intelligence, which allows persons to visualize objects from different perspectives and orientations, thus 
making it possible to detect and focus on new ways of approaching situations, phenomena and territorial systems, with optimal decisions for each case. Everybody has the capacity to obtain, understand, process and communicate information presented in three dimensions -from the most basic level that is the location, and which it is characterized by such aspects as texture, shape, colour and the relationship between these qualities (Newcombe \& Frick, 2010; Van Schaik, 2008).

Taking the Cognitive Theory of Multimedia (CTML) as a starting point, one can find possible explanations of why digital resources such as AR, digital mapping and MPN can improve learning processes. In this context, the definition offered by Mayer (2009) is perhaps the best option. It states that people learn best through the use of combined resources of words and patterns (images), above and beyond the use of mere words. In particular, the principle underlying the empirical structures that are proposed here is precisely the signalling principle, which states that people learn best when there are signs that display the essential information in an organized manner, within the learning environment established. Thus, the AR resources, mobile mapping and MPN can be implemented by creating proper signalling elements for study, thus guiding students by means of information on geographical location and with visual references to digital resources.

\section{Related work}

The existing literature on AR in the context of field work, and on mobile mapping and MPN, has been examined from different points of view. This has been done through research ranging from theoretical studies, with predominantly qualitative characteristics based on focus groups and interviews, to empirical studies on the results of these technologies in the learning process. Topics covered range from the teaching of engineering-related contents, like mathematics and science, the teaching of history and artistic, and literary contents (Dunleavy \& Dede, 2014). A first revision focused on studies using various parameters adapted from FitzGerald (2012): device or technology used for the deployment of AR technology, mode of interaction between user and contents, method of sensory feedback for the users, type of experience (individual or group), implementation region and type of participants in the experiment (Table 1). The analysis of the related works is based on two general criteria, the first of which is the publication date of available papers. Only articles whose publication date does not exceed five years in the past (January 2012 to 2015) were considered. The second criterion was the geographical representativeness of the investigations, considering at least one item per region. Although other experiences that make use of AR and MPN (Jamali, Shiratuddin, \& Wong, 2014; Satpute, Pingale, \& Chavan, 2015; Wei, Weng, Liu, \& Wang, 2015) were found, their research focused on the teaching of STEM contents, or on the evaluation of dimensions different from those considered in this paper.

These studies establish that the use of AR in education has taken place mainly in universities, in engineering and science degrees, although one can also find experiences in museums and schools with interesting results. Most of the experiences involved using static display technologies for AR (PC desktops and quick response markers) with specific information models displaying three-dimensional models such as simplified geometric shapes, polygons or small objects. In addition, these experiences were intended for elementary school students with prebuilt three-dimensional resources, and with contents that belonged to the curriculum of each reality.

Table 1: Educational Experiences with AR.

\begin{tabular}{|c|c|c|c|c|c|c|c|}
\hline Name of project & $\begin{array}{c}\text { Device or } \\
\text { technology } \\
\text { used }\end{array}$ & Interaction mode & $\begin{array}{l}\text { Method } \\
\text { sensory } \\
\text { feedback to } \\
\text { the user }\end{array}$ & $\begin{array}{l}\text { Type of } \\
\text { Experie } \\
\text { nce: } \\
\text { Personal } \\
\text { or group }\end{array}$ & $\begin{array}{l}\text { Region of } \\
\text { Implement } \\
\text { ation }\end{array}$ & Participants & Learning activities \\
\hline $\begin{array}{l}\text { GLUEPS-AR } \\
\text { (Muñoz } \\
\text { Cristóbal et al., } \\
\text { 2014) }\end{array}$ & $\begin{array}{l}\text { Desktop PC } \\
\text { / Tablets / } \\
\text { Smartphone } \\
\quad \text { s }\end{array}$ & $\begin{array}{l}\text { Passive / assimilative by } \\
\text { information layer. Active / } \\
\text { exploratory (data } \\
\text { recording / query tools). }\end{array}$ & $\begin{array}{l}\text { Mixed: } \\
\text { Visual (VG, } \\
\text { 3D), text, } \\
\text { video. }\end{array}$ & $\begin{array}{l}\text { Personal } \\
\text { and in } \\
\text { groups }\end{array}$ & Europe & $\begin{array}{l}\text { College } \\
\text { students }\end{array}$ & $\begin{array}{l}\text { System that aims to put in } \\
\text { practice territorial } \\
\text { scenarios with physical } \\
\text { and virtual elements. }\end{array}$ \\
\hline $\begin{array}{c}\text { AR in } \\
\text { documents and } \\
\text { images (Diego } \\
\text { Obregón, 2014) }\end{array}$ & $\begin{array}{l}\text { Desktop PC } \\
\text { / Tablets / } \\
\text { Smartphone } \\
\text { s }\end{array}$ & $\begin{array}{c}\text { Passive / assimilative by } \\
\text { information layer. } \\
\text { Exploratory display } \\
\text { models. }\end{array}$ & $\begin{array}{l}\text { Mixed: } \\
\text { Visual (VG, } \\
\text { 3D), text, } \\
\text { video. }\end{array}$ & $\begin{array}{l}\text { Personal } \\
\text { and in } \\
\text { groups }\end{array}$ & Europe & $\begin{array}{l}\text { Elementary } \\
\text { students }\end{array}$ & $\begin{array}{c}\text { Students create a book } \\
\text { with content on AR about } \\
\text { Peninsula de la } \\
\text { Magdalena (Santander) }\end{array}$ \\
\hline $\begin{array}{c}\text { ARLE: } \\
\text { Augmented } \\
\text { Reality } \\
\text { Learning } \\
\text { Environment } \\
\text { (Arribas, } \\
\text { Gutiérrez, Gil, } \\
\text { \& Santos, 2014) }\end{array}$ & $\begin{array}{l}\text { Tablets / } \\
\text { Smartphone } \\
\text { s }\end{array}$ & $\begin{array}{l}\text { Passive / assimilative by } \\
\text { information layer. Active / } \\
\text { exploratory (data } \\
\text { recording / query tools). }\end{array}$ & $\begin{array}{l}\text { Mixed: } \\
\text { Visual (VG, } \\
\text { 3D), text, } \\
\text { video. }\end{array}$ & Personal & Europe & $\begin{array}{l}\text { Teachers and } \\
\text { high school } \\
\text { students. }\end{array}$ & $\begin{array}{l}\text { Learning environment } \\
\text { based on multimedia } \\
\text { content AR with } \\
\text { electricity and } \\
\text { electronics. }\end{array}$ \\
\hline $\begin{array}{c}\text { Proyecto } \\
\text { espiRA } \\
\text { (Reinoso, 2012) }\end{array}$ & $\begin{array}{c}\mathrm{PC} / \\
\text { Tablets / } \\
\text { Smartphone } \\
\mathrm{S}\end{array}$ & $\begin{array}{c}\text { Passive / assimilative by } \\
\text { information layer. } \\
\text { Exploratory display } \\
\text { models. }\end{array}$ & $\begin{array}{l}\text { Mixed: } \\
\text { Visual (VG, } \\
\text { 3D), text, } \\
\text { video. }\end{array}$ & $\begin{array}{l}\text { Personal } \\
\text { and in } \\
\text { groups }\end{array}$ & Europe & $\begin{array}{l}\text { Teachers and } \\
\text { high school } \\
\text { students. }\end{array}$ & $\begin{array}{c}\text { Project content with } \\
\text { geolocation and AR } \\
\text { through a user-friendly } \\
\text { platform. }\end{array}$ \\
\hline
\end{tabular}


Joo-Nagata, J., Martínez Abad, F., García-Bermejo Giner, J., \& García-Peñalvo, F. J. (2017). Augmented reality and pedestrian navigation through its implementation in m-learning and e-learning: Evaluation of an educational program in Chile. Computers \& Education, 111, 1-17. doi:10.1016/j.compedu.2017.04.003

\begin{tabular}{|c|c|c|c|c|c|c|c|}
\hline $\begin{array}{l}\text { Proyecto Saltet } \\
\text { (Ramirez \& } \\
\text { Cassinerio, } \\
\text { 2014) }\end{array}$ & Tablets & $\begin{array}{c}\text { Passive / assimilative by } \\
\text { information layer. } \\
\text { Exploratory display } \\
\text { models. }\end{array}$ & $\begin{array}{l}\text { Visual with } \\
\text { 3D models }\end{array}$ & $\begin{array}{l}\text { Personal } \\
\text { and in } \\
\text { groups }\end{array}$ & $\begin{array}{c}\text { Latin } \\
\text { America }\end{array}$ & $\begin{array}{l}\text { Elementary } \\
\text { students }\end{array}$ & $\begin{array}{l}\text { Using AR in 5-year-old } \\
\text { children with content on } \\
\text { road traffic, water cycle, } \\
\text { the human skeleton and } \\
\text { senses, in a context of } \\
\text { collaborative work. }\end{array}$ \\
\hline $\begin{array}{c}\text { L-ELIRA, } \\
\text { learning } \\
\text { industrial } \\
\text { elements means } \\
\text { augmented } \\
\text { reality } \\
\text { (Martín } \\
\text { Gutiérrez \& } \\
\text { Meneses } \\
\text { Fernández, } \\
\text { 2014) }\end{array}$ & Desktop PC & $\begin{array}{c}\text { Passive / assimilative by } \\
\text { information layer. } \\
\text { Exploratory display } \\
\text { models. }\end{array}$ & $\begin{array}{l}\text { Visual with } \\
\text { 3D models }\end{array}$ & Personal & Europe & $\begin{array}{l}\text { College } \\
\text { students }\end{array}$ & $\begin{array}{l}\text { Improving spatial } \\
\text { abilities, motivation, and } \\
\text { academic performance of } \\
\text { engineering students }\end{array}$ \\
\hline $\begin{array}{l}\text { AR in informal } \\
\text { learning } \\
\text { environments } \\
\text { (Sommerauer } \\
\text { \& Müller, 2014) }\end{array}$ & Tablets & $\begin{array}{c}\text { Passive / assimilative by } \\
\text { information layer. } \\
\text { Exploratory display } \\
\text { models. }\end{array}$ & $\begin{array}{l}\text { Mixed: } \\
\text { Visual (VG, } \\
\text { 3D), text, } \\
\text { video. }\end{array}$ & $\begin{array}{l}\text { Personal } \\
\text { and in } \\
\text { groups }\end{array}$ & Europe & $\begin{array}{l}\text { Heterogeneou } \\
\text { s sample }\end{array}$ & $\begin{array}{l}\text { Mathematics exhibition } \\
\text { to measure the effect of } \\
\text { AR on acquiring and } \\
\text { retaining mathematical } \\
\text { knowledge in an informal } \\
\text { learning environment. }\end{array}$ \\
\hline $\begin{array}{l}\text { AR in a mobile } \\
\text { guidance } \\
\text { (Chang et al., } \\
\text { 2015) }\end{array}$ & Tablets & $\begin{array}{c}\text { Passive / assimilative by } \\
\text { information layer. } \\
\text { Exploratory display } \\
\text { models. }\end{array}$ & $\begin{array}{l}\text { Mixed: } \\
\text { Visual (VG, } \\
\text { 3D), text, } \\
\text { video. }\end{array}$ & $\begin{array}{l}\text { Personal } \\
\text { and in } \\
\text { groups }\end{array}$ & Asia & $\begin{array}{l}\text { College } \\
\text { students }\end{array}$ & $\begin{array}{l}\text { AR guidance promoted } \\
\text { sense of place and } \\
\text { learning performance. }\end{array}$ \\
\hline $\begin{array}{l}\text { EcoMOBILE: } \\
\text { AR experience } \\
\text { with use of } \\
\text { environmental } \\
\text { field trip } \\
\text { (Kamarainen et } \\
\text { al., 2013) }\end{array}$ & $\begin{array}{l}\text { Smartphone } \\
\mathrm{s}\end{array}$ & $\begin{array}{l}\text { Passive / assimilative by } \\
\text { information layer. Active / } \\
\text { exploratory (data } \\
\text { recording / query tools). }\end{array}$ & $\begin{array}{l}\text { Mixed: } \\
\text { Visual (VG, } \\
\text { 3D), text, } \\
\text { video. }\end{array}$ & $\begin{array}{l}\text { Personal } \\
\text { and in } \\
\text { groups }\end{array}$ & $\begin{array}{c}\text { North } \\
\text { America }\end{array}$ & $\begin{array}{l}\text { Elementary } \\
\text { students a }\end{array}$ & $\begin{array}{l}\text { AR application, to } \\
\text { navigate the pond } \\
\text { environment and to } \\
\text { observe virtual media and } \\
\text { information overlaid on } \\
\text { the physical pond. }\end{array}$ \\
\hline
\end{tabular}

In a general context, most investigations made use of AR for teaching spatial skills within fixed environments, which were established in classrooms and formal educational environments. Sommerauer \& Müller (2014) designed a pre-test/post-test crossover field experiment in an exhibition intended to show mathematics content, trying to measure the effect of $A R$ on the acquisition and retention of content in a non-formal learning environment (a museum). The experience produced significant performance improvements when using AR in comparison with exhibits that did make use of this tool. On the other hand, Martín-Gutierrez et al (2014) studied the effect of AR on learning spatial skills, motivation, and academic performance, in relation to geometry, using as a basis a book with AR methods in a context of desktop PC. Through a class context pre-test/post-test with 49 students, the group using the tool of AR showed a significant gain in spatial skills, compared to the group that worked with traditional elements of teaching. Kamarainen et al. (2013), within the context of ubiquitous learning theory, used AR and field work to design an educational activity within the framework of teaching contents on science and ecosystems in elementary school, evaluating the experience through a survey of students and analysing comments from teachers. Results showed an increase inmeasurements on understanding of content by students and a better perception of these educationar resources by teachers. Also, from the context of mobility and content on heritage, Chang, Hou, Pan, Sung, \& Chang (2015), developed an application that combines AR and a mobile context in order to study the theory of sense of place from the start of interpretation. This was done with mobile tools for historical content, with the result that students who used the AR achieved a significantly better learning when compared to students who worked with traditional tools. In the study of the state of the subject in the educational field, the use of digital mapping of devices, in combination with AR, is not established. While there is an exception stated in Kamaranien et al. (2013), where the presence of geolocalized AR is evidenced, in the educational activity proposed in the study, digital cartography was not used as a means of evaluating learning with technology. In this regard, it is important to mention that research proposing the combination of digital maps and AR in a context of mobility, are established in other fields, such as tourism (Fino, Martín-Gutiérrez, Fernández, \& Davara, 2013; Pendit, Zaibon, \& Abubakar, 2015), city planning (Graham, Zook, \& Boulton, 2013; Kim \& Han, 2014), heritage (Cayla, 2014; Martinez-Grana, Goy, \& Cimarra, 2013), engineering (W. Huang, Sun, \& Li, 2016) or computing science (Albrecht \& Lokki, 2015; Rehman \& Cao, 2017), where we do not find formal educational evaluations of these tools as a whole.

In summary, the few experiences carried out in Latin America concerning the use of AR in education are limited to a qualitative methodology, with few empirical results that establish important references on the subject under study. There is not much presence in appropriate journals and related publications. On the other hand, experiences carried out in other parts of the world suggest significant quantitative evidence of AR and MPN in educational environments producing improved student learning. However, one must say that the use of these tools in fieldwork and in contexts of formal education is inconclusive - particularly when applied to the teaching of heritage, history and social sciences-. The results of using combined methodologies, such as field work with AR technology, are inconclusive. This is due to 
the fact that most of the studies were carried out in classrooms, and further the type of content to be taught focused on science, mathematics and engineering.

\section{Material and methods}

\subsection{Design}

This paper starts from a mixed perspective, since we applied quantitative and qualitative methods to identify and measure factors related to the acquisition of content for each instance analysed. Thus, the objectives of the research are developed in two major areas: the implementation of contents on heritage and the development of an educational assessment tool in a context of formal education. For the first dimension, contents related to territorial heritage elements of the city of Santiago de Chile were selected an analysed from an educational point of view. This was done in order to define and adapt the contents to a context of digital presentation for mobile devices. In parallel, we carried out the development of a mobile application and another for a desktop computer. Both of them made use of AR-MPN elements that showed Location (through digital mapping), Navigation and AR resources. This was done, more precisely, in programs for mobile devices and in web applications for web browsers in desktop computers. These applications were intended to display the previously elaborated contents on heritage and territory of the city, depending on the context m-learning or e-learning. The teaching experience was complemented with the incorporation of learning assessment tools, that would later be used in an objective multiple-choice test. The test would be carried out as quasi-experimental pre-test/post-test in a real educational scenario (Campbell \& Stanley, 1966). Therefore, we have chosen two educational scenarios to carry out the implementation of treatments with AR, maps and navigation. A first scenario was based on fieldwork in the previously selected sectors of the city, making use of AR and MPN on tablets in an m-learning context (the experimental group). The second scenario was a classroom with desktop PCs using an AR application as well as map servers, in an environment that was that of traditional classroom e-learning (the control group). For each case, the dependent variable (learning level) would be measured before and after the completion of the educational activity, for each of the proposed student groups (Fig. 1).

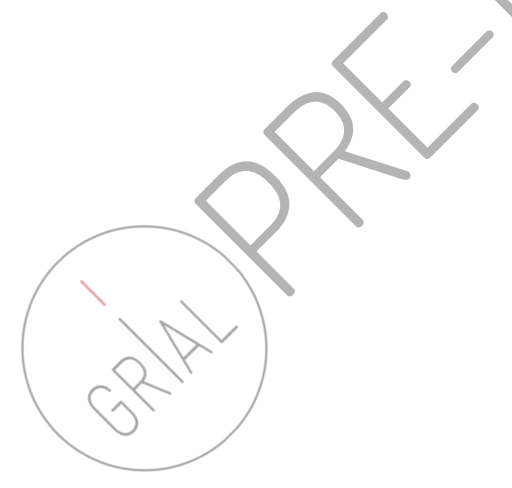


Joo-Nagata, J., Martínez Abad, F., García-Bermejo Giner, J., \& García-Peñalvo, F. J. (2017). Augmented reality an pedestrian navigation through its implementation in m-learning and e-learning: Evaluation of an educational program in Chile. Computers \& Education, 111, 1-17. doi:10.1016/j.compedu.2017.04.003

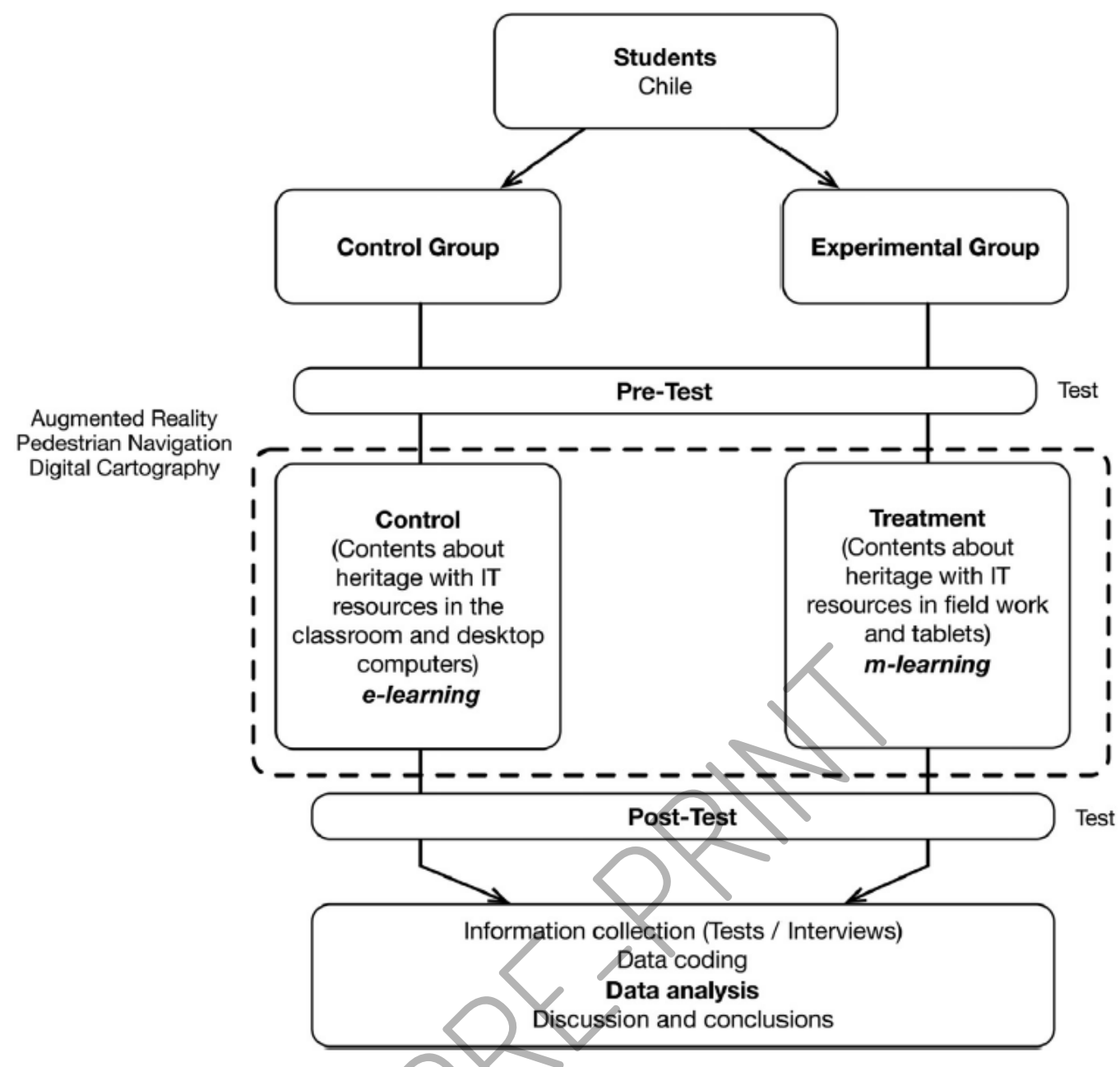

Fig. 1. Quasi-experimental research structure

\subsection{Participants and sample}

The sample used for research consists of 143 subjects of which 72 participated in the fieldwork (m-learning) and 71 in classroom work (e-learning). Students belonged to two schools in the city of Santiago de Chile. The sample includes a diversity of characteristics regarding gender. The treatment of heritage resources used in educational contexts (Table 2) is also not exactly the same for both groups.

Table 2: General characteristics of students $(n=143)$

\begin{tabular}{|c|c|c|c|c|c|}
\hline \multicolumn{2}{|c|}{ Gender } & \multicolumn{2}{c|}{ School } & \multicolumn{2}{c|}{ Treatment } \\
\hline Female & Male & School 1 & School 2 & m-learning & e-learning \\
\hline 75 & 68 & 67 & 76 & 72 & 71 \\
$(52.45 \%)$ & $(47.55 \%)$ & $(46.15 \%)$ & $(53.15 \%)$ & $(50.35 \%)$ & $(49.65 \%)$ \\
\hline
\end{tabular}

Regarding the population of elementary-school students, their ages range between 12 and 14 years, and their number in Santiago is known to be $\mathrm{N}=237.45$ (Ministerio de Educación Chile, 2015). This implies a level of significance $\alpha=.05$ and a maximum level of homogeneity $\mathrm{p}=\mathrm{q}=0.5$. For a sample size of 143 subjects, a sampling error of $8.2 \%$ is obtained (Arnal, Rincón, \& Latorre, 1992). Due to the nature of research with a quasi-experimental approach structure, it was not possible to obtain greater sample sizes as a consequence of constraints on time and resources. Thus, to ensure the representativeness of the sample obtained, a hypothesis testing of the correspondence between the theoretical distributions and the sample was carried out by means of a goodness of fit test based on Chi Square.

In the case of School \#1, the value of the test statistic is $\chi_{1 ; .05}^{2}=0.529>\chi^{2}=0.396$, hence $\mathrm{H}_{0}$ is accepted, where the sample distribution fits the population to the level of primary education. Regarding School \#2, the value of the test statistic is $\chi_{1 ; .05}^{2}=0.79>\chi^{2}=0.06$, hence $\mathrm{H}_{0}$ is accepted too, where the sample distribution fits the population for the grade of primary education. 
Joo-Nagata, J., Martínez Abad, F., García-Bermejo Giner, J., \& García-Peñalvo, F. J. (2017). Augmented reality anđ pedestrian navigation through its implementation in m-learning and e-learning: Evaluation of an educational program in Chile. Computers \& Education, 111, 1-17. doi:10.1016/j.compedu.2017.04.003

In the case of interviews, the number of participants accounted for 3 teachers $(n=5)$ and 5 students $(n=143)$, which were selected in a context of samples by opportunity (Teddlie \& Yu, 2007). In the case of teachers, only subjects who participated in the planned educational activities were interviewed, and in the case of students, interviews were made to students that were extreme cases, that is, to students with the highest values in the test (3) and also with the lowest levels (2).

\subsection{Variables}

The dependent variable is related to the knowledge acquired by students about heritage. It is determined regarding a theme about cultural heritage, using as a basis the definition of a sector of the city of Santiago de Chile. This was done because of the historical and heritage elements present in this sector, in which buildings and architectural landmarks allow the proper implementation of educational activities and resources. In the selection of buildings and places for the development of a heritage thematic context, it was necessary to compile and study spatial information. This was achieved, in practice, by means of a file prepared by specialists from different areas and contexts related to the theme that was to be used in our educational implementation: teachers, historians, anthropologists, geographers and architects. These persons helped with the contextual definition of the data collection instrument for its subsequent digital implementation. Regarding the independent variable, it is related to the methodological aspect applied to the experimental group (m-learning with tablets). In parallel, the control group consists of students who worked in an e-learning context, with desktops. Thus, for both implementations, the same thematic contents were applied by means of similar software for each type of tool used. From the heritage thematic context for the city of Santiago de Chile, 57 monuments were defined in an area covering approximately 250.16 hectares (Fig 2).

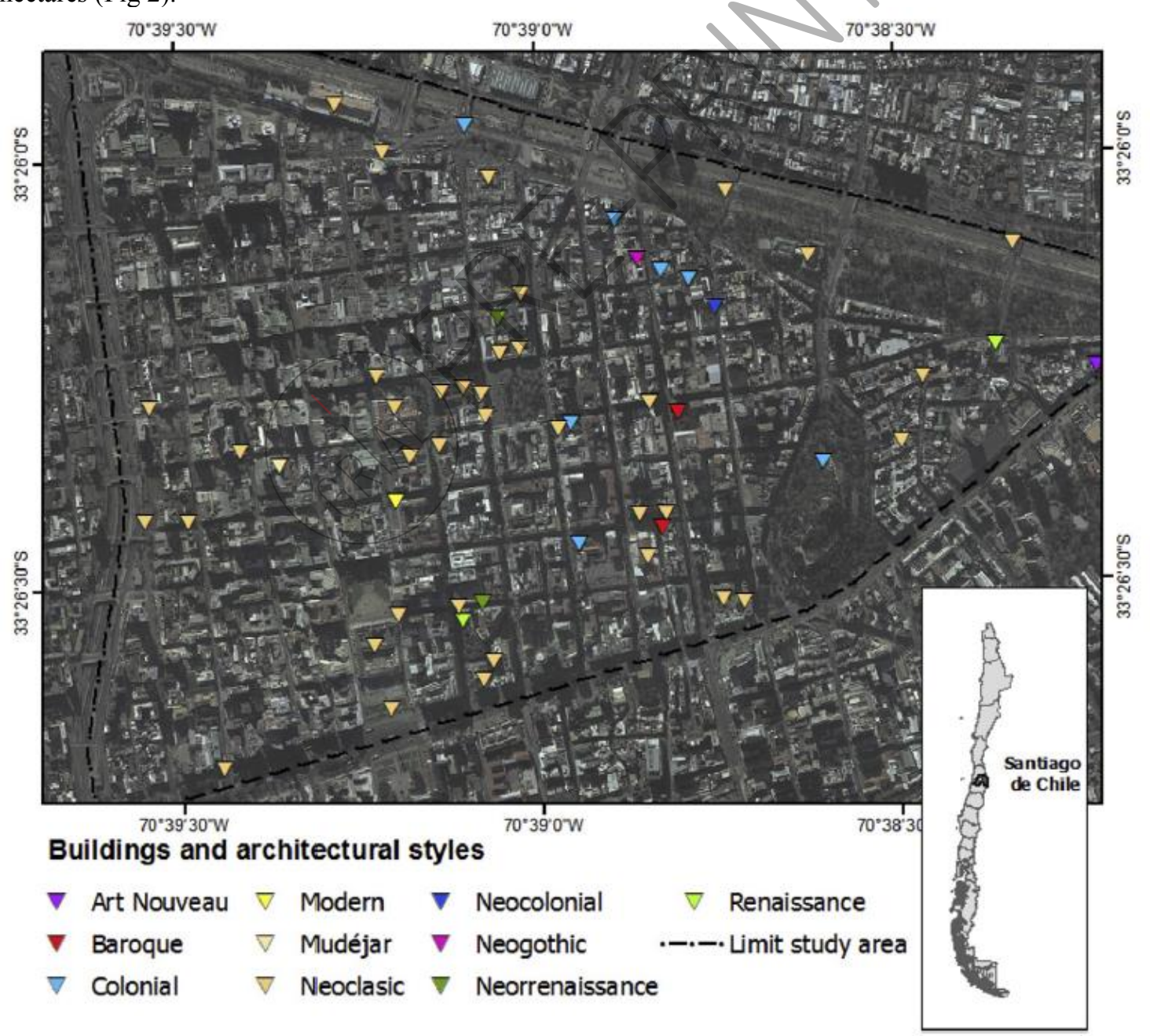

Fig. 2: Study area, Santiago de Chile and points of heritage interest. 
Joo-Nagata, J., Martínez Abad, F., García-Bermejo Giner, J., \& García-Peñalvo, F. J. (2017). Augmented reality anđ pedestrian navigation through its implementation in m-learning and e-learning: Evaluation of an educational program in Chile. Computers \& Education, 111, 1-17. doi:10.1016/j.compedu.2017.04.003

In parallel, the AR-MPN application was developed in a portable and mobile ecosystem (tablets ${ }^{1}$ ), based on various frameworks: Apple Maps for spatial visualization system (MPN) and georeferencing and Junaio for deploying AR resources (Mathias \& Gallagher, 2015), all of them supported by the underlaying iOS operating system (Fig.3).
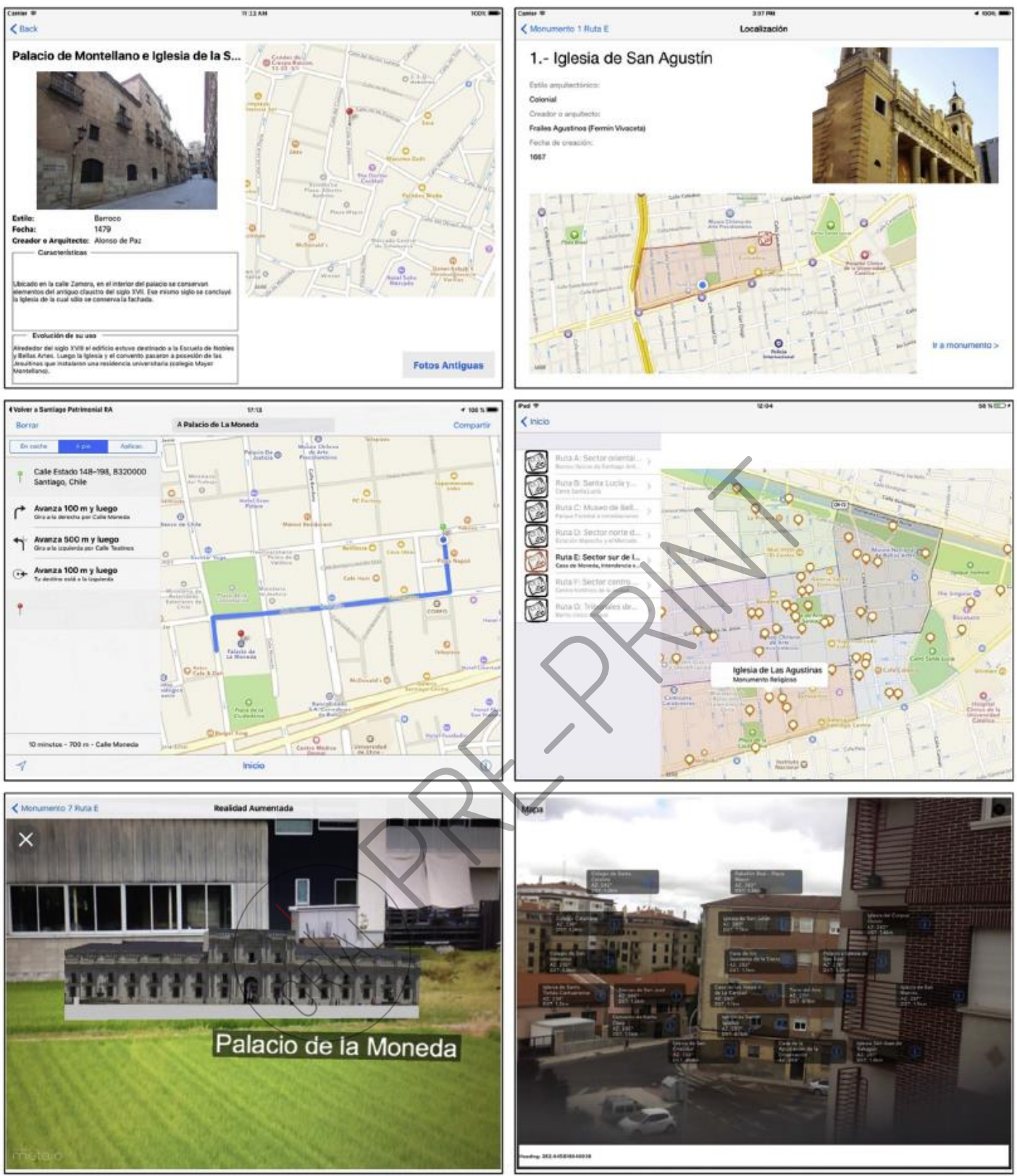

Fig. 3 Structure of the mobile application

Thus, the AR-MPN application for the experimental group was implemented according to the territorial extension defined in the study area and also according to the characteristics of the information on heritage agreed upon. Of course, this implied taking the factors obtained in the spatial analysis of the data into account, as well as the interaction with other elements within the boundaries of the previously defined territory, and also the educational objectives intended to be achieved. So, a navigation proposal that guided students in the educational process about the heritage theme of the city was generated. Thus, the following elements are implemented in the application. Firstly, a general view of the proposed territorial landmarks displayed on a digital map, with automatic adaptation of the territorial vision based on the position of the device. In the second place, there exists the possibility of generating different spatial scales of representation according to user requirements. And thirdly, the user is offered the visualization and

\footnotetext{
${ }^{1}$ The hardware selected for this experience corresponds to Apple Inc. iPad tablets, whose characteristics are: screens between 7.9" to 9.7". Its iOS operating system meets all requirements for implementing software AR and MPN.
} 
Joo-Nagata, J., Martínez Abad, F., García-Bermejo Giner, J., \& García-Peñalvo, F. J. (2017). Augmented reality and pedestrian navigation through its implementation in m-learning and e-learning: Evaluation of an educational program in Chile. Computers \& Education, 111, 1-17. doi:10.1016/j.compedu.2017.04.003

consultation of other urban phenomena represented (Fig 3). In the case of the desktop PC application (control group), students performed educational activities by viewing digital resources on a platform, said resources made in a context of learning objects (Arango, Gaviria, \& Valencia, 2015; García Holgado, García Peñalvo, Zangrando, \& Seoane Pardo, 2013). Teachers work as general guides of the activity, and complement it with information presented in the devices. Further, they urge students to reflect on phenomena displayed on devices, and also to exchange ideas. Of course, this is done in the context of realworld scenario in which the activity developed. A piece of software called eXeLearning 2.0.4 was used for e-learning experience. This software makes it possible to create and publish educational content in an HTML format (Fig. 4). In the case of MPN in the context of Desktop PCs, Google Maps was used for navigation and Cloud Cities for digital terrain models. For elements in AR, models were used in Junaio, complemented with a webcam in a desktop PCs environment (Table 3).

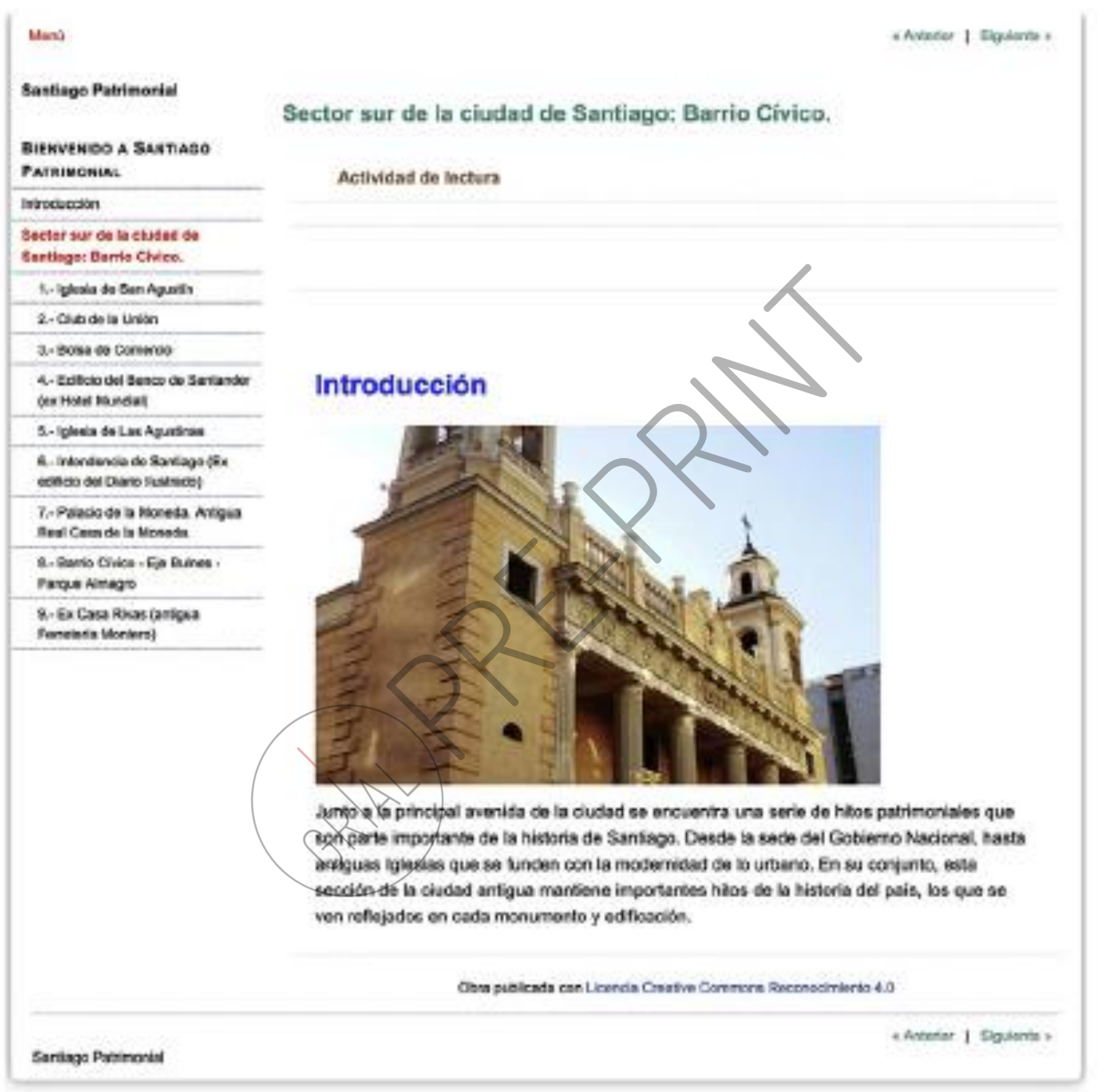

Fig. 4 eXeLearning used to implement the educational experience in a classroom (Desktop PC)

Table 3: Points about heritage of the city and implementation of digital educational resources

\begin{tabular}{|l|l|}
\hline Content for the city of Santiago de Chile & \multicolumn{1}{c|}{ Resources } \\
\hline Milestone 1: Church of Saint Agustín & AR model, old photographs and informative text \\
\hline Milestone 2: Club de La Unión & $\begin{array}{l}\text { AR models, informational text, old photographs and } \\
\text { digital maps. }\end{array}$ \\
\hline $\begin{array}{l}\text { Milestone 3: Neighbourhood Nueva York, } \\
\text { La Bolsa and Club de la Unión }\end{array}$ & $\begin{array}{l}\text { AR models, informational text, old photographs and } \\
\text { digital maps. }\end{array}$ \\
\hline $\begin{array}{l}\text { Milestone 4: Bolsa de Comercio } \\
\text { Old photographs and informative text. }\end{array}$ \\
\hline $\begin{array}{l}\text { Milestone 5: Building of Banco de } \\
\text { Santander (ex Hotel Mundial) }\end{array}$ & Old photographs and informative text. \\
\hline Milestone 6: Church Las Agustinas & Old photographs and informative text. \\
\hline $\begin{array}{l}\text { Milestone 7: Intendencia de Santiago } \\
\text { (before building of Diario Ilustrado) }\end{array}$ & $\begin{array}{l}\text { AR models, informational text, old photographs and } \\
\text { digital maps. }\end{array}$ \\
\hline
\end{tabular}


Joo-Nagata, J., Martínez Abad, F., García-Bermejo Giner, J., \& García-Peñalvo, F. J. (2017). Augmented reality and pedestrian navigation through its implementation in m-learning and e-learning: Evaluation of an educational program in Chile. Computers \& Education, 111, 1-17. doi:10.1016/j.compedu.2017.04.003

\begin{tabular}{|c|c|}
\hline $\begin{array}{l}\text { Milestone 8: Palacio de la Moneda. } \\
\text { Antigua Real casa de la Moneda }\end{array}$ & $\begin{array}{l}\text { AR models, informational text, old photographs and } \\
\text { digital maps. }\end{array}$ \\
\hline $\begin{array}{l}\text { Milestone 9: Civic neighbourhood - streets } \\
\text { Bulnes - Parque Almagro }\end{array}$ & Informational text, old photographs and digital maps. \\
\hline $\begin{array}{l}\text { Milestone 10: Ex Casa Rivas, previously } \\
\text { "Ferretería Montero" }\end{array}$ & $\begin{array}{l}\text { AR models, informational text, old photographs and } \\
\text { digital maps. }\end{array}$ \\
\hline
\end{tabular}

\subsection{Instruments}

The designed pre-test/post-test instrument measures three general dimensions to assess the implementation of applications. The first one is the general identification by means of the elements of location and description about buildings that will be used in the activity. A second dimension measures knowledge on the historical and heritage background of the building including the description of their context. Finally, there is an educational dimension, which measures e-learning derived from heritage elements of the building. The level of knowledge achieved by students (learning or dependent variable) before and after application of treatment for both groups, was measured with a test that consisted of 25 items with 4 response options. This test was applied in a traditional way (paper and pencil), incorporating a unique identifier in order to compare the marks obtained pre-test and post-test (Martínez, Navarro, \& Sánchez, 2012; Martínez Abad, 2013; Martínez Clares \& Echeverría Samanes, 2009). The instrument was evaluated by 12 expert judges, determining the quality of each item of the test according to 4 criteria: Adaptation to the proposed educational level of activity (primary education); clarity of items form the point of view student understanding; accuracy with which the test items assess the proposed contents (historical and temporal context; architectural and urban morphological elements; and location and spatiality); and finally relevance to basic skill levels proposed in Bloom's taxonomy-knowledge, understanding and application-.

For validation of test items (with dichotomous variables), an analysis that includes the Index of Difficulty was made (Abad, Olea, Ponsoda, \& García, 2011; Rodríguez Conde, 2011), the Index of Discrimination (Abad et al., 2011), and finally the Point Biserial Correlation Discrimination Index $-r_{b p}-$ (Abad et al., 2011). Pre-test results shows a high difficulty in most of its items (15\% to $40 \%$ correct answers). Once treatments had been applied for groups, post-test results show different amounts of difficulty in. There is 1 very easy item, then 9 easy items, 8 items of moderate difficulty, and finally 7 items that were difficult for students. From the results of the Discrimination Index, post-test results establish that 4 items have low discrimination value, 7 items have a good discrimination, 11 items have very good discrimination, and 3 items do not allow discrimination. The latter were removed for further analysis. Regarding the results obtained for $\mathrm{r}_{\mathrm{bp}}$, all values obtained by this indicator in the post-test have strong positive values $\left(r_{b p}>.150\right)$, except for a single item having a negative value, which it was discarded for further analysis of the test.

An additional test was applied to subjects, once the educational experience had been completed: it was a satisfaction survey validated and used in other investigations (Favier \& van der Schee, 2012). The test dealt with the exercise performed from the point of view an ICT context, of the materials used, of the proposed contents, and of their respective implementation (Table 4).

Table 4. Specifications for the satisfaction survey

\begin{tabular}{|l|c|c|}
\multicolumn{1}{|c|}{ Question/ affirmation } & Codification & \multicolumn{1}{|c|}{ Dimension } \\
\hline 1. I'm not comfortable using the application & [ITEM_1] & Application - Implementation \\
\hline $\begin{array}{l}\text { 2. The application gives me confidence in the use of tablets (or PC } \\
\text { Desktops) }\end{array}$ & [ITEM_2] & Hardware \\
\hline 3. It is easy to navigate within the application used & [ITEM_3] & Application - Implementation \\
\hline $\begin{array}{l}\text { 4. The information displayed in the application is not always accurate } \\
\text { 5. The application has been given a positive impression of the contents } \\
\text { about heritage }\end{array}$ & [ITEM_4] & Application - Contents \\
\hline $\begin{array}{l}\text { 6. The application has given me important information for my learning } \\
\text { 7. The graphic design of the application is not visually appealing }\end{array}$ & Application - Contents \\
\hline 8. It is difficult to use the application & [ITEM_7] & Application - Contents - \\
\hline 9. I was given enough information for the use of the application & [ITEM_8] & Application - Implementation - Implementation \\
\hline 10. I like the information that shows the application & [ITEM_9] & Application - Implementation \\
\hline
\end{tabular}

The types of questions have as a possible answer a Likert scale with 5 levels, ranging from "strongly agree" (5) to "very disagree" (1). The reliability of this survey, by Cronbach's Alfa, acquires a value of 0.765 , which is taken by some authors to be enough for a standard exploratory analysis (Loewnthal, 1996; Nunnally, 1978). 
For the qualitative dimension, structured interviews were conducted (Brinkmann, 2014; Martín Izard, 2011; Vela Peón, 2001), where, from a predetermined script, ordered and directed, questions are posed to obtain the necessary information in the context of the investigation. This is presented as an instrument with final modality in order to know the perception of the subjects, their impressions, feelings, etc., about the experience and about the tool used in a learning context. In this way, once the evaluation results of the test were known, we proceeded to the choice of subjects for the application of the interview. Depending on the groups of subjects interviewed some particular application parameters for the interview were defined (Kvale, 2007). In students, a general introduction to the activity to be performed was set, which explained the context of the interview, introduced the interviewer to them, and elicited data on the subject to be interviewed (age, grade, family group, number of years spent on the school). The default duration of the interview was 30 minutes, and the closure of the activity included reading points raised in the conversation, in order to correct or to complete some information Further, the student was consulted about the possibility of adding some element or comments that he or she considered important to mention. Regarding teachers, the same general presentation was established, explaining the purpose of the interview that was to take place. In parallel, they were consulted on the context of their educational work (educational expertise, experience in the work area, how many years had they been part of the school staff). The duration of the interview was 45 minutes on average, and the closure of the activity was established with the reading of the points raised and obtained with the dialogue of questions and answers. This was done so that teachers could make corrections, make observations or complete any information provided by them.

\subsection{Data analysis}

In addition, a number of statistical techniques were applied to the results of the test and of the interviews, in order to measure the validity of these instruments. Techniques were, both psychometric and exploratory (descriptive, correlational, inferential and multivariate. The starting point in this case was the Classical Test Theory (Abad et al., 2011; Muñiz, 2010). Before the corresponding analysis, the values obtained in the test were transformed to a T scale, with a mean value of 50 and a standard deviation of 15 , in order to make it possible to compare the results obtained from the pre-test and post-test instruments Firstly, we carried out the determination of the density functions in order to check whether the sample fits a normal distribution. In addition, we applied Levene's test, which allows contrasting the goodness of fit with respect to the homogeneity or homoscedasticity of variances (Martínez Abad, 2013). Subsequently, an exploratory data analysis is performed with the position -percentiles-, dispersion measurements variance, standard deviation, coefficient of variation and range-, and measures of shape sample -skewness, kurtosis- (Hernández, Fernández, \& Baptista, 2010; Nieto Martín, 2011). In the statistical hypothesis testing applying parametric tests performed using Student's $t$, if the data are normally distributed, in order to compare the dependence or independence of two variables - difference mean for related samples(Hernández et al., 2010). An analysis of variance with repeated measures -ANOVA-MR- was also performed (Berlanga Silvente \& Rubio Hurtado, 2012; Pardo Merino, 2002), in order to study the effect of treatments in an intra-subject context, that is, the context pre-test/post-test performed with the educational experience. Additionally we calculate the power of the test and the effect size, which is based on the statistical g of Hedges for the test t (Cárdenas Castro \& Arancibia Martini, 2014; Mayr, Buchner, Erdfelder, \& Faul, 2007), determining the probability of superiority (Grissom \& Kim, 2011), and the effect size based on the correlation (Corder \& Foreman, 2009) in the case of using the nonparametric test. For the application of these statistical analysis and hypothesis testing, softwares used were IBM SPSS 21 and R version 3.2.1. Indicators of effect size and statistical power, were obtained by software G*Power 3.1.6.

Applied the Kolmogorov-Smirnov test for normality assumption of the samples obtained, we obtained as pre-test values for the treatment group m-learning $\mathrm{z}=0.852$ y $\mathrm{p}=0.463$, and for the control group e-learning $\mathrm{z}=1.324 \mathrm{y} \mathrm{p}=0.06$, with no significant differences in scores between the groups before conducting educational activities proposed. In addition, the values obtained in the Box's M test indicate that the variance-covariance matrices of the groups are homogenous $(M=2.464$ and $p=0.489)$. These results justify the relevance of implementing an analysis of variance with repeated measures (Berlanga Silvente \& Rubio Hurtado, 2012; Pardo Merino, 2002), in order to study the effect of treatment in a context, both intrasubject and inter-subject that is, both at the level pre-test/post-test and at the level of treatment or educational experience.

As regards qualitative data analysis, we carried out the analysis of the interviews using categories previously defined by Yang (2013). A segmentation of the unique elements of information that are important for research was performed. Once we obtained the first categories of information derived from interviews, we began to group and sort these items around the general concept of learning technology resources. Thus we defined the relevant dimensions, variations and important elements, defining subcategories (Tables 5 and 6). 
Joo-Nagata, J., Martínez Abad, F., García-Bermejo Giner, J., \& García-Peñalvo, F. J. (2017). Augmented reality and pedestrian navigation through its implementation in m-learning and e-learning: Evaluation of an educational program in Chile. Computers \& Education, 111, 1-17. doi:10.1016/j.compedu.2017.04.003

This categorization system was represented as networks (Fig. 7 and 8) that established the relationships between codes and categories. These networks express the conditions, contexts and dimensions in which the phenomena of research are presented. This analysis was performed by means of Atlas TI 7.5.4.

Table 5: Category system used in the interview for teachers

\begin{tabular}{|c|c|c|}
\hline Category & Subcategory & Code \\
\hline \multirow{2}{*}{$\begin{array}{l}\text { 1. Social-specific background. } \\
\text { sociodemographic elements of teachers }\end{array}$} & Social and educational context & PRO1.1 \\
\hline & Family-technological context & PRO1.2 \\
\hline \multirow{3}{*}{$\begin{array}{l}\text { 2. Personal use of technology. Attitudes } \\
\text { and features that give the technology in } \\
\text { their personal lives. }\end{array}$} & Experience with technology & PRO2.1 \\
\hline & Attitudes towards technology & PRO2.2 \\
\hline & Type in the use of educational tool. & $\mathrm{PRO} 2.3$ \\
\hline \multirow{6}{*}{$\begin{array}{l}\text { 3. Use of technology in educational } \\
\text { contexts. Attitudes and capabilities that } \\
\text { give technology teacher professional } \\
\text { field. }\end{array}$} & Technological perception in formal educational settings & PRO3.1 \\
\hline & $\begin{array}{l}\text { Use of ICT in educational activities. } \\
\text { Teaching with technology }\end{array}$ & PRO3.2 \\
\hline & Getting educational objectives & PRO3.3 \\
\hline & Adaptation of ICT resources & PRO3.4 \\
\hline & Teaching strategies with ICT. & PRO3.5 \\
\hline & Interaction with students in ICT contexts & PRO3.6 \\
\hline \multirow{6}{*}{$\begin{array}{l}\text { 4. Evaluation of the experience, from the } \\
\text { personal and professional point of view }\end{array}$} & Perception of fieldwork activity for learning & PRO4.1 \\
\hline & Educational perception of digital maps and MPN & PRO4.2 \\
\hline & Educational perception about $\mathrm{AR}$ & PRO4.3 \\
\hline & Educational perception about tablets & PRO4.4 \\
\hline & Limitations of the resources used in educational experiences & PRO4.5 \\
\hline & Feeling around these experiences (tablets and PC desktop). & PRO4.6 \\
\hline
\end{tabular}

Table 6: Category system used in the interview for students

\begin{tabular}{|c|c|c|}
\hline Category & Subcategory & Code \\
\hline \multirow{5}{*}{$\begin{array}{l}\text { 1. Social-specific background. } \\
\text { sociodemographic elements of students } \\
\text { 2. Personal use of technology. Attitudes } \\
\text { and features that give the technology in } \\
\text { their personal lives }\end{array}$} & Social and educational context & EST1.1 \\
\hline & Family-technological context & EST1.2 \\
\hline & Experience with technology & EST2.1 \\
\hline & Attitudes towards technology & EST2.2 \\
\hline & $\begin{array}{l}\text { Typology technological tools in the personal and professional } \\
\text { use }\end{array}$ & EST2.3 \\
\hline \multirow{8}{*}{$\begin{array}{l}\text { 3. Use of technology in educational } \\
\text { context. Attitudes and capabilities that } \\
\text { students give the technology in formal } \\
\text { learning } \\
\text { 4. Evaluation of the experience, from the } \\
\text { personal sense of students }\end{array}$} & Technological perception in formal educational settings & EST3.1 \\
\hline & $\begin{array}{l}\text { Use of ICT in educational activities. Formal learning with } \\
\text { technology. }\end{array}$ & EST3.2 \\
\hline & Strategies used by students for learning with ICT tools. & EST3.3 \\
\hline & Interaction between students, in ICT and learning contexts. & EST3.4 \\
\hline & Educational perception of digital maps and MPN & EST4.1 \\
\hline & Educational perception about $\mathrm{AR}$ & EST4.2 \\
\hline & Educational perception about tablets & EST4.3 \\
\hline & Feeling around these experiences (tablets and PC desktop). & EST4.4 \\
\hline
\end{tabular}

\section{Results}

\subsection{Descriptive analysis}

An exploratory analysis of the data obtained was performed, which turned out to be in line with expected results (Table 7). Low values in the pre-test, suggest that students from both groups have the same initial levels; it was in the post-test where an increase in scores showed significant differences in the values obtained in the test results obtained according to the treatment used.

Table 7: Descriptive statistics of pre-test/post-test results

\begin{tabular}{|c|c|c|c|c|c|c|c|c|c|c|c|c|c|c|c|}
\hline & \multicolumn{5}{|c|}{ Pre-Test Score } & \multicolumn{5}{|c|}{ Post-Test Score } & \multicolumn{5}{|c|}{ Gain Scores } \\
\hline & $\mathrm{M}$ & $\mathrm{Mdn}$ & SD & Min & Max & M & Mdn & SD & Min & Max & $\mathrm{M}$ & Mdn & SD & Min & Max \\
\hline $\begin{array}{l}\text { m-learning with } \\
\text { AR-MPN in } \\
\text { fieldwork }\end{array}$ & 5.04 & 5 & 2.38 & 0 & 11 & 13.57 & 13 & 3.88 & 3 & 20 & 8.53 & 8 & 4.83 & -5 & 18 \\
\hline $\begin{array}{l}\text { e-learning with } \\
\text { AR, Maps } \\
\text { servers and } \\
\text { traditional class }\end{array}$ & 5.23 & 5 & 2.19 & 0 & 9 & 11.08 & 11 & 4.22 & 3 & 20 & 5.85 & 6 & 4.64 & -4 & 18 \\
\hline
\end{tabular}


Thus, the data establish that there exists an intra-subject variation, with an increase in student scores after applying the assigned treatments, and inter-subject variations, where students who performed the m-learning activity performed better compared to those who used e-learning in their post-test scores. Figure 5 shows how this trend are clearly visible.

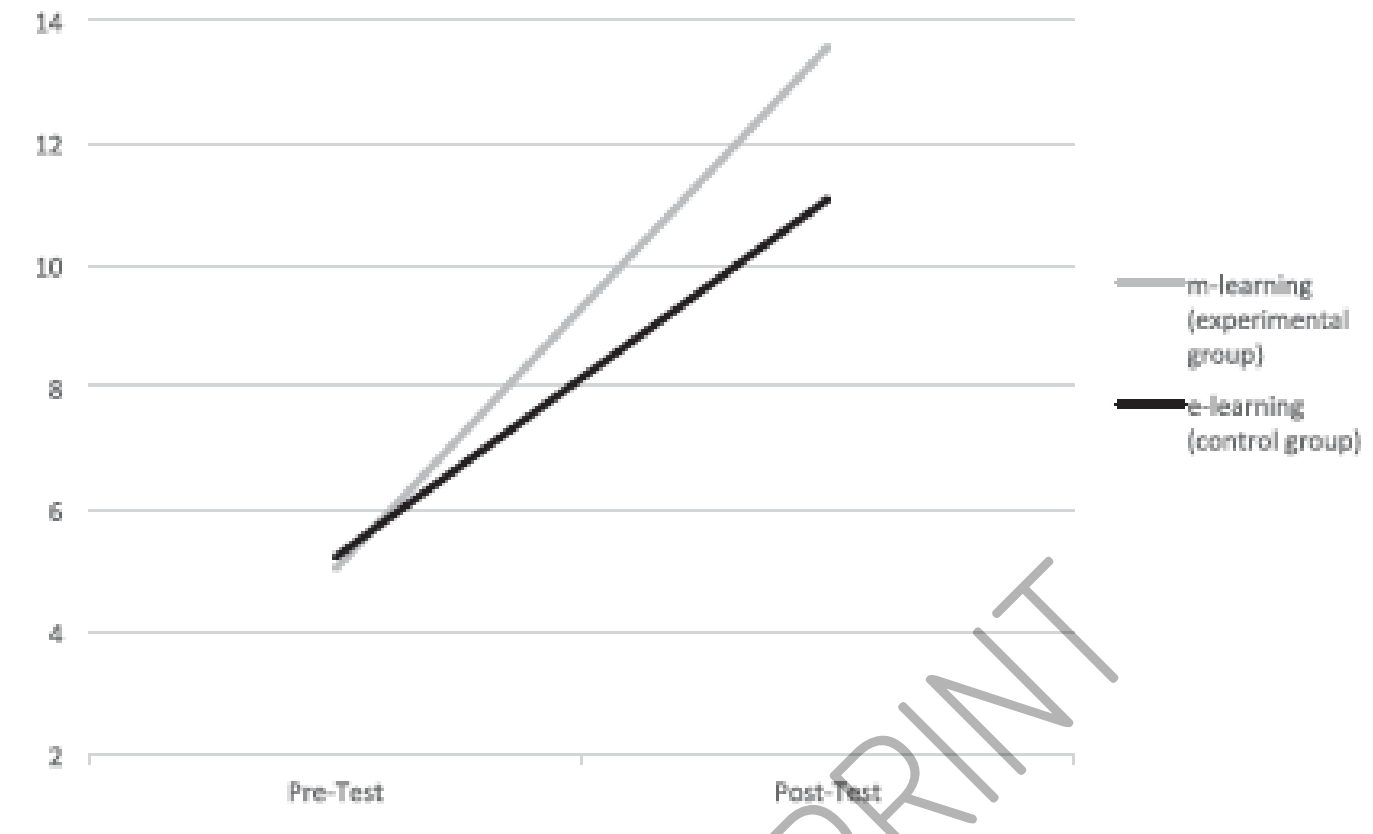

Fig. 5. Means comparison pre-test and post-test, or grouping $(n=143)$

\subsection{Hypothesis Contrast}

Thus, the results obtained in the main effects model (Table 8), confirm that all subjects achieved significantly higher yields in the post-test, regardless of the assigned experimental situation, and that this effect is highly significant $(\mathrm{F}=328.65 ; \mathrm{p} .<.001)$. Therefore, we can say that all students show generally a statistically significant progress in the post-test compared to pre-test, that is, that there are intra-subject effects. On the other hand, significant effects obtained in the interaction between the two levels of treatment $(\mathrm{F}=11.31 ; \mathrm{p} .=.001)$ provide evidence of the different effects that both treatments (e-learning and $\mathrm{m}$ learning) have had on the subject. This also confirms the existence of inter-subject effects associated with the two levels assigned in treatment.

Table 8: Hypothesis contrast. Difference in averages-median pre-test/post-test

\begin{tabular}{|c|c|c|c|c|c|}
\hline & & $\mathbf{F}$ & $\mathbf{P}$ & $\begin{array}{c}\text { Partial Eta square } \\
\left(\eta^{2}\right)\end{array}$ & Test's Power \\
\hline \multirow{2}{*}{ Total criterion } & Main effect & 328.647 & $<.001$ & .700 & $100.00 \%$ \\
\cline { 2 - 6 } & Interaction & 11.308 & .001 & .074 & $91.60 \%$ \\
\hline
\end{tabular}

Regarding the importance of the main effect, the size of the growth effect on the whole group is evident, $\left(\eta^{2}=.700\right)$, with this result being confirmed by the average values obtained in both the pre-test and post-test. Since there is an interaction effect on the values found, it would not be appropriate to interpret those obtained directly main effects, it is more appropriate to determine the localized effects in the prepost/post-test effects separately for each group. Table 9 shows the results of the test for related groups, implemented for each of the two groups.

Table 9: Hypothesis testing related groups pre-test/post-test

\begin{tabular}{|c|c|c|c|}
\hline & $\mathbf{t}$ & $\mathbf{P}$ & G Hedges \\
\hline $\begin{array}{c}\text { m-learning (experimental } \\
\text { group) }\end{array}$ & -14.956 & $<.001$ & 2.17 \\
\hline e-learning (control group) & -10.621 & $<.001$ & 1.36 \\
\hline
\end{tabular}


Joo-Nagata, J., Martínez Abad, F., García-Bermejo Giner, J., \& García-Peñalvo, F. J. (2017). Augmented reality and pedestrian navigation through its implementation in m-learning and e-learning: Evaluation of an educational program in Chile. Computers \& Education, 111, 1-17. doi:10.1016/j.compedu.2017.04.003

From the context of each group, analyses establish that there are statistically significant differences between pre-test / post-test values for both experimental groups $(\mathrm{t}=-14.956 ; \mathrm{p}<.001)$ as well as for the control group $(\mathrm{t}=-10.621 ; \mathrm{p}<.001)$. Regarding the effect sizes, important differences are also observed, obtaining moderately higher values in the experimental group $(\mathrm{g}=2.17)$ compared to the control group ( $\mathrm{g}$ $=1.36$ ), although both cases can be considered high magnitude effects (Cohen, 1969). When an intersubject statistical test is performed by separating the application in the pre-test and post-test stages, it can be established, on the one hand, that in pre-test measurement, no significant differences exist between groups $(t=-0.479$ and $p=.663)$. Thus, subjects start at a similar level scores, and the homogeneity of the students who participated in the educational experiences is confirmed. Furthermore, in the post-test measurements, the comparison between experimental and control groups returned significant differences $(\mathrm{t}$ $=3.662$ and $\mathrm{p}<.001$ ), which translates to higher scores for the m-learning group.

\subsection{Satisfaction survey about the educational experiences}

In the m-learning context, we notice that the item that has a greater acceptance among the participating subjects corresponds to $\mathrm{n}^{\mathrm{o}} 3$ ("It is easy to navigate within the application used"), which is based on the ease of navigation within the implemented application. These results are followed by item $n^{\circ}$ 8 ("It is easy to use the application"), which delivers clues about the usability of the device and the application in a mobile environment. Items with lower scores $\left(n^{\circ} 4\right.$ and 7$)$ are related to the graphic resources of the contents, although the values obtained do not indicate disapproval, but rather to a sense of indifference in the display elements of the mobile application (Fig. 6).

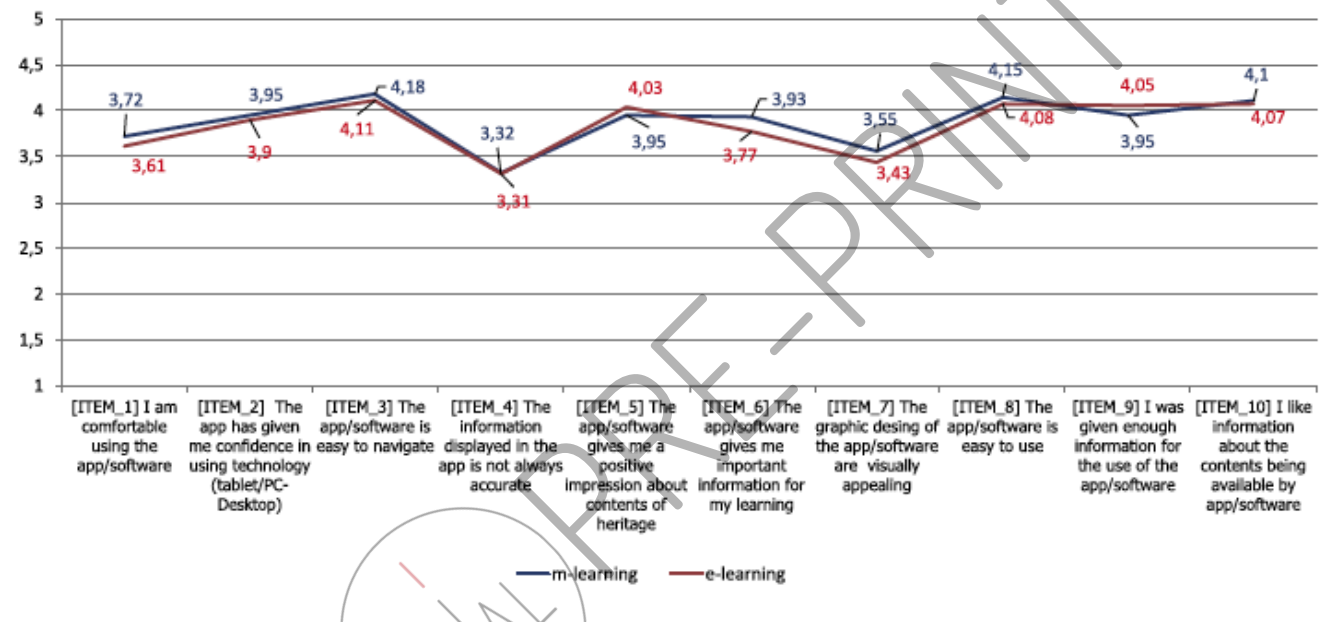

Fig. 6: Satisfaction survey results according to educational experience

When satisfaction levels are evaluated regarding the e-learning experience, the item that shows the highest performance corresponds to $\mathrm{n}^{\mathrm{o}} 6$, related to the whole educational process implementation carried out ("the application has been delivered important information for my learning").

To complement the analysis, we applied the $t$ test for independent samples using the total values for each item of the scale, in order to obtain relevant information on whether there are statistically significant differences in the perception of applications, due to the type of educational experience performed by students (m-learning o e-learning). The Kolmogorov-Smirnov test is applied to the sample, where the significance of the data obtained is equal to 0.207 , with an average of 39.031 and a standard deviation of 6.626, which results in a normal distribution of values. Applying the statistical test of Levene, values state that the requirement homoscedasticity of data is met $(F<0.001: p=0.982)$, resulting in the acceptance of the null hypothesis in the $t$ test $(t=0.390 ; p=0.697)$. This implies that there are no significant differences in perception of the m-learning group versus treatment with e-learning. Both of the implemented treatments have the same perception of students as an educational activity.

\subsection{Qualitative results}

Having established the results on the different processes and content with the proposed activities from the point of view of quantitative analysis, the perception of teachers and students was studied in depth through a qualitative analysis of interviews in which selected members of both populations participated. Generally, teachers showed a positive perception about these tools, with variations around specific elements derived from personal experience. The main aspects under examination were the use of thematic content 
Joo-Nagata, J., Martínez Abad, F., García-Bermejo Giner, J., \& García-Peñalvo, F. J. (2017). Augmented reality and pedestrian navigation through its implementation in m-learning and e-learning: Evaluation of an educational program in Chile. Computers \& Education, 111, 1-17. doi:10.1016/j.compedu.2017.04.003

with ICT, the technological implementation, and in particular the role of teachers when these tools are incorporated into teaching activities (Fig. 7).

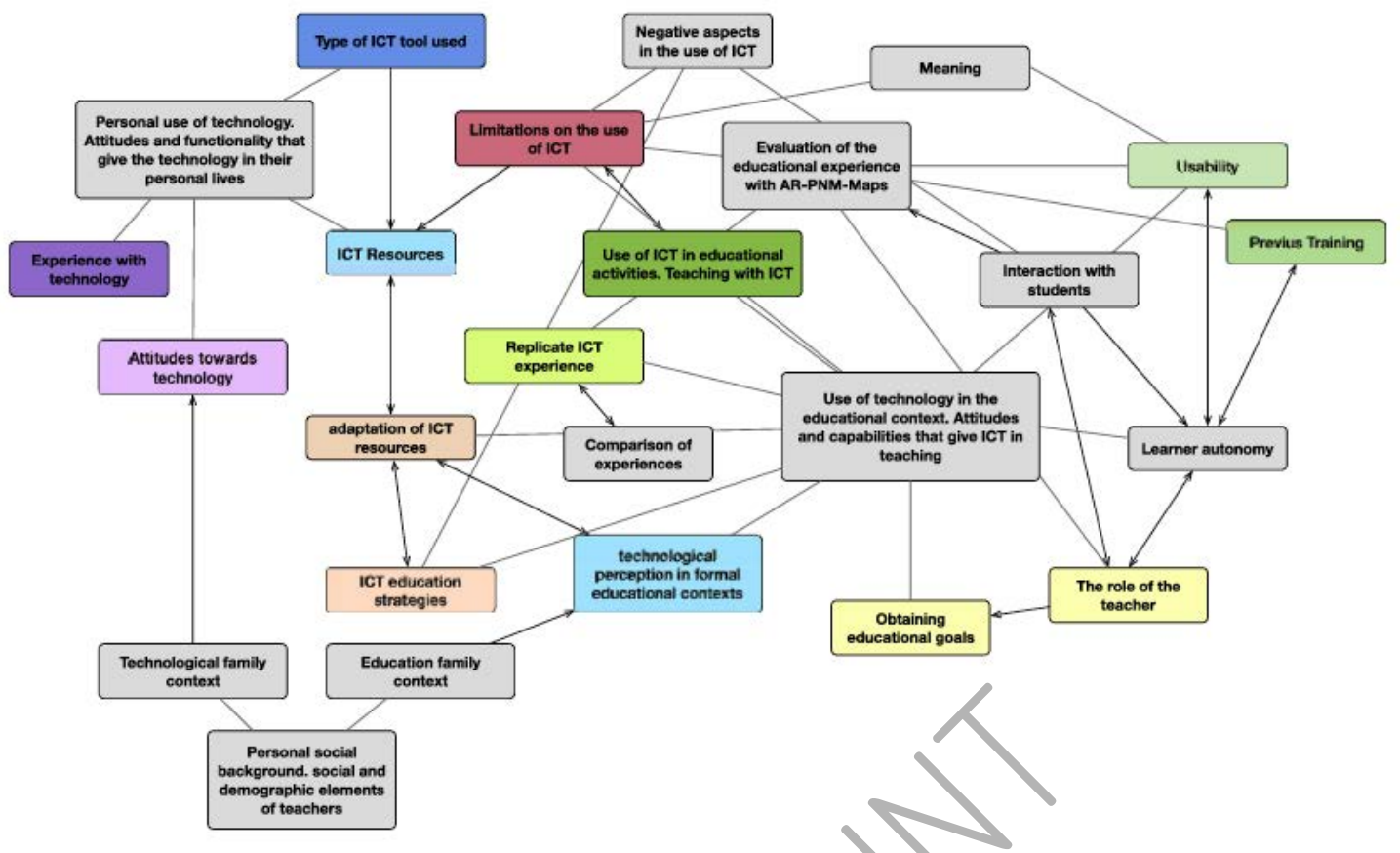

Fig. 7: Relations between categories and codes in interviews with teachers.

Within this area, there is a constant reference to the possible autonomy of the learning process that could be performed by students, particularly, in a context of fieldwork and m-learning, where real and virtual elements complement each other:

Teacher 1: The application was good for them to work alone and I felt that was very good, because they began to explore... sometimes they left the precise zone of heritage under study, but they found they could make use of Maps and maybe that helped them see that they could use a technology they did not know.

Teacher 2: I found the app to be good teaching material, because students can locate the heritage, they can observe "in situ" the different artistic ensembles, identify their characteristics, learn curiosities, appreciate how these buildings were formerly through old pictures, see the characteristics of its construction, and aerial view (augmented reality X Provided a proper operation, the possibilities presented for students and teaching staff are numerous.

Another element that came up frequently in interviews was the role that teachers should have in educational activities related to digital cartography, AR and MPN tools, particularly regarding m-learning activity. The opinions of the interviewees are divided into two types of perceptions: teachers who bet on a mediating role, and those who bet on the autonomy of the students.

Teacher 3: Students are too used to having a teacher nearby to guide the fieldwork, to resolve all doubts that they have, either language or content questions, or about the context in which the building was... (about resources in AR and maps).

Teacher 1: Yes... then I thought that they, let's say they understood much, finally they understood the use of the tablet and I felt it was not necessary to be given further explanation, because information was there on the device. 


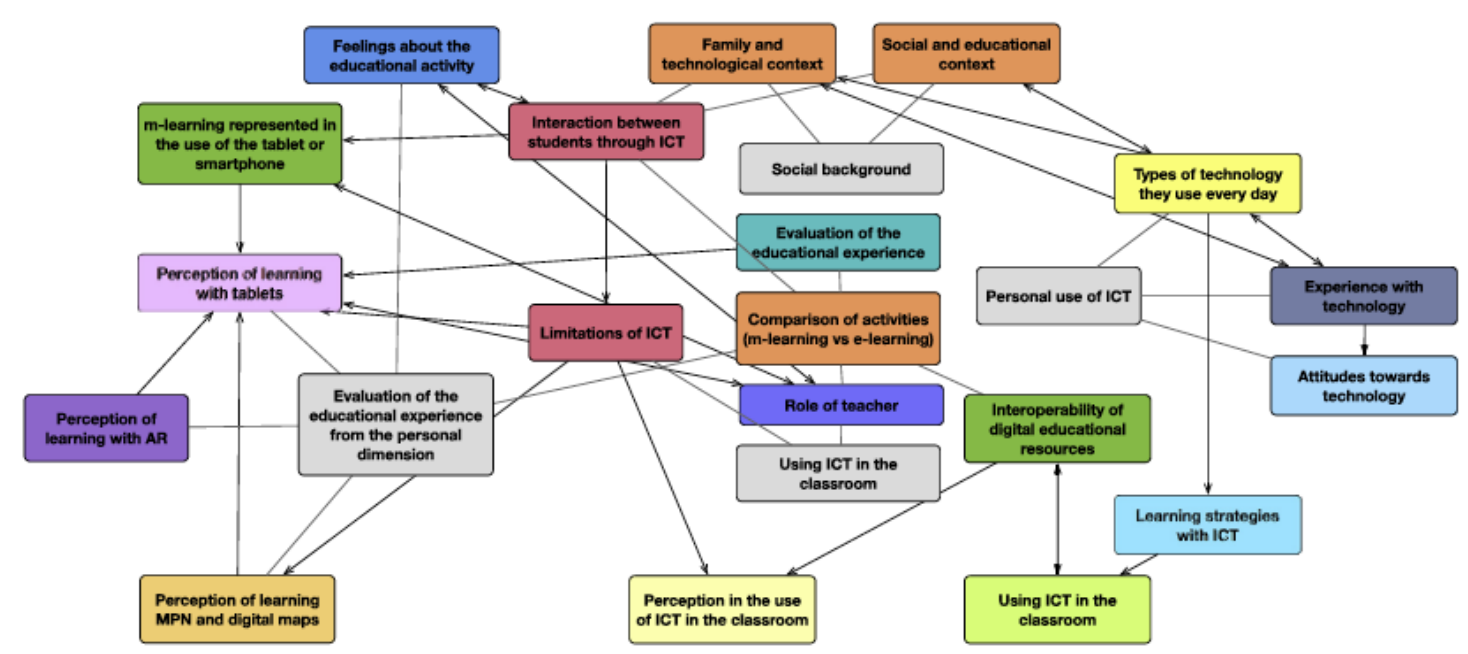

Fig. 8: Relations between categories and codes in interviews with students.

When students were consulted about the m-learning activity performed, their opinions and general comments were positive, highlighting the teaching methodology significance of the activity, by means of the interactions with the mobile device, and the context of fieldwork presented. In addition, the opinion on how to measure the educational process (test) appears, which was mentioned by one interviewee with very positive elements in their assessment (Fig. 8).

Student 1: At the beginning I did not understand much, because we had to push as many parts, but I did like it, because when I was walking, it was marking the course, it was easier to get to the place, and old images also showed up... for example, a church and I did not even know how they were before, and then instead of having to search for the old image in Google, images were right there.

Student 2: I found it quite good (the application), because, although places are always there, we have no idea about their history, why they were there, and what they do there, and... the use of technology was good because we did not know that other applications were there that helped us know more sites of our city.

All these dimensions and variables are represented as relations of various kinds, among which one must highlight association, belonging or condition. Thus, a structure that composes the discourse of students is established, ranging from their own perception of ICT (general and personal context), to the work of educational activity with AR-MPN, together with their assessments and impressions. The contexts of personal background are also included, as well as the use of technology in conventional educational settings, which are related to other variables both directly and indirectly.

\section{Discussion}

Two main techniques are essential in the design of the app, both of which cooperate well in a context of mobility: AR and MPN. There is a wide range of libraries that implement these tools for mobile contexts, with different features, costs, options, and available platforms. From the point of view of educational research, the right implementation of these resources must go hand in hand with the interaction between the mobile system and the user (student). It must provide simple and self-explanatory graphical user interfaces, in addition to the interoperability of AR models with location data, to simplify their usage in m-learning contexts.

From the quantitative point of view, the goal was that of evaluating the application created by establishing the effectiveness of such technological resources as AR, MPN and digital cartography, on the processes of acquiring knowledge, understanding, and application about contents on heritage and social sciences, in a context of m-learning with tablets. This was to be done in comparison to similar methodologies, but applied in different contexts (e-learning). To test our assertion, a methodological process was followed, from a scientific perspective, which included the assessment of each of the stages of design, from the selection of heritage content that will be taught, to a thorough review of the tests applied to students. 
With the results divided according to the type of treatment that was used for each educational experience, it can be established that there are statistically significant differences in learning among students who used tablets and mobile application, with respect to working with traditional PC Desktops. The size of the effects obtained were of high magnitude $\left(\eta^{2}=0.70\right)$, in contrast to the findings of other researchers like Sommerauer et al. (2014) and Aim-Lim et al. (2014), where these experiments produced medium or low effects $\left(r=0.36\right.$ and $\left(\eta^{2}=0.02\right)$.

In addition, while both groups showed significant increases in their final scores after the activities, students that worked in an m-learning context had better outcomes compared to students who only participated in e-learning situations, confirming the results of other investigations that proceeded along this line (Al-Qahtani \& Higgins, 2013; Friess, Oliver, Quak, \& Lau, 2016; Furió, Juan, Seguí, \& Vivó, 2014).

From the point of view of the satisfaction survey, results state that IT deployments had a high acceptance among students. They were perceived as innovative and original tools, contextualized in an educational activity, and overcoming the casual and everyday use with which it is associated. This is in accordance with results presented in other studies (Martín Gutiérrez \& Meneses Fernández, 2014). In summary, the general perception of participating students is centred around a nominal value "agree" for all the statements established in the survey, resulting in a positive result from the field of satisfaction with the activity, which is above the learning indicators obtained in previous stages. Similar findings were present in other investigations (Martín Gutiérrez \& Meneses Fernández, 2014; Sommerauer \& Müller, 2014). A limitation of this section is related to the determination of other factors affecting the results, rather than to the statistical processing performed.

The results from the qualitative dimension, with interviews to teachers, suggest that there is a positive perception of the incorporation of these tools to formal education. There exists a point of disagreement concerning the role that should be played by the teacher, who can be seen as mediator between the class and the computing resources, but could also just allow the independent work of students. This situation that has already been raised in other studies with other ICT resources (Favier \& van der Schee, 2012). Regarding the results of interviews with students, testimonies show that there is a high acceptance of these methods, and, particularly when real elements are implemented (in fieldwork) as well digital information, they produce better academic achievements. This situation that has already been described in other studies (Chang et al., 2015; Friess et al., 2016).

One of the strengths of this research is the comparison of results obtained in two different scenarios of formal education (e-learning and m-learning) in which similar digital contents were used for learning. The necessary external validity was generated in this way, considering further that participating students had the same academic level before the application of the respective treatments. This comparison of scenarios and teaching methodologies makes it possible to estimate the differences and relative effectiveness of each situation.

It is necessary to improve such aspects as the creation of a more complex assessment tool; it should not be based just on multiple choice questions and it should use other types of resources in evaluation. It is also necessary to strengthen the measurement of such aspects as understanding and application (problem resolution), which are established in the taxonomy of Bloom, beyond mere knowledge acquisition. From the qualitative methodological aspect, interviews with students were conditioned by the scenario in which it was made (school), which could have influenced the answers, perceptions and attitudes about the educational activities performed.

Possible directions to be followed in future research work concern three fundamental aspects: the first is to strengthen the theoretical contexts, particularly as related to CMTL and ubiquitous-learning, to contexts updated theories about m-learning and e-learning, and taking them to more specific areas. A second line of work is the replication of experiences in different levels and educational backgrounds, thus creating learning resources for other disciplines that use this kind of fieldwork but different contents (ecology, geology, sciences, environment). Finally, it is necessary to establish the degree of relevance of fieldwork and the use of technological elements within a context of ubiquitous learning (Y.-M. Huang, Chiu, Liu, \& Chen, 2011), allowing to reach a different level of analysis of these apps, facilitating their comparison with other educational processes implemented.

\section{Conclusions}

From the empirical results, given the results of the implementation of a software intended to show a context of thematic and territorial information, is established as conclusion that from a context m-learning and e-learning, it is possible to implement a design of an educational experience about of heritage contained in the territory, with widely positive results. The addition of such resources as AR, MPN, and digital cartography in devices like tablets and PC Desktops, has proven effective in general learning processes of local content and heritage elements. In this research, students who have used tablets in fieldwork (m- 
Joo-Nagata, J., Martínez Abad, F., García-Bermejo Giner, J., \& García-Peñalvo, F. J. (2017). Augmented reality an® pedestrian navigation through its implementation in m-learning and e-learning: Evaluation of an educational program in Chile. Computers \& Education, 111, 1-17. doi:10.1016/j.compedu.2017.04.003

learning) compared to students who used PC Desktop devices in classroom (e-learning), had better scores on almost all elements of content and processes, establishing that the m-learning is more effective compared to traditional e-learning. Future lines of work are intended to show the reproducibility of this research, with the use of AR, MPN, and digital cartography in other teaching scenarios associated with other disciplines, thus making it possible to know how students interact in different thematic and territorial contexts, and approaching a near u-learning implementation and the evaluation of its educational effectiveness. Reproducibility at other levels such as tertiary education or informal education contexts is also desirable.

\section{References}

Abad, F. J., Olea, J., Ponsoda, V., \& García, C. (2011). Medición en ciencias sociales y de la salud (1st ed.). Madrid: Sintesis.

Ai-Lim Lee, E., \& Wong, K. W. (2014). Learning with desktop virtual reality: Low spatial ability learners are more positively affected. Computers \& Education, 79, 49-58. https://doi.org/10.1016/j.compedu.2014.07.010

Albrecht, R., \& Lokki, T. (2015). Auditory Distance Presentation in an Urban Augmented Reality Environment. Acm Transactions on Applied Perception, 12(2), 5. https://doi.org/10.1145/2723568

Al-Qahtani, A. A. Y., \& Higgins, S. E. (2013). Effects of traditional, blended and e-learning on students' achievement in higher education. Journal of Computer Assisted Learning, 29(3), 220-234. https://doi.org/10.1111/j.1365-2729.2012.00490.x

Arango, J., Gaviria, D., \& Valencia, A. (2015). Differential Calculus Teaching through Virtual Learning Objects in the Field of Management Sciences. Procedia - Social and Behavioral Sciences, 176, 412-418. https://doi.org/10.1016/j.sbspro.2015.01.490

Arnal, J., Rincón, D. del, \& Latorre, A. (1992). Investigación educativa: fundamentos y metodologías. Editorial Labor.

Arribas, J. C., Gutiérrez, S. M., Gil, M. C., \& Santos, A. C. (2014). Recursos digitales autónomos mediante Realidad Aumentada. RIED. Revista Iberoamericana de Educación a Distancia, 17(2). Retrieved from http://revistas.uned.es/index.php/ried/article/download/12686/11880

Berlanga Silvente, V., \& Rubio Hurtado, M. J. (2012). Clasificación de pruebas no paramétricas. Cómo aplicarlas en SPSS. Reire. Revista d'Innovació I Recerca En Educació, 5(2), 101-113. https://doi.org/10.1344/reire2012.5.2528

Brinkmann, S. (2014). Unstructured and Semi-Structured Interviewing. In P. Leavy (Ed.), The Oxford handbook of qualitative research (pp. 277-299). New York: Oxford University Press.

Campbell, D. T., \& Stanley, J. C. (1966). Experimental and quasi-experimental designs for research. Boston: Houghton Mifflin Company.

Cárdenas Castro, M., \& Arancibia Martini, H. (2014). Potencia estadística y cálculo del tamaño del efecto en G*Power: complementos a las pruebas de significación estadística y su aplicación en psicología. Salud \& Sociedad, 5(2), 210-224.

Cayla, N. (2014). An Overview of New Technologies Applied to the Management of Geoheritage. Geoheritage, 6(2), 91-102. https://doi.org/10.1007/s12371-014-0113-0

Chang, Y.-L., Hou, H.-T., Pan, C.-Y., Sung, Y.-T., \& Chang, K.-E. (2015). Apply an Augmented Reality in a Mobile Guidance to Increase Sense of Place for Heritage Places. Educational Technology \& Society, 18(2), 166-178.

Cohen, J. (1969). Statistical power analysis for the behavioural sciences. New York: Academic Press.

Corder, G. W., \& Foreman, D. I. (2009). Nonparametric Statistics for Non-Statisticians: A Step-by-Step Approach (1st ed.). Hoboken, N.J: Wiley.

Crompton, H., Burke, D., Gregory, K. H., \& Gräbe, C. (2016). The Use of Mobile Learning in Science: A Systematic Review. Journal of Science Education and Technology, 1-12. https://doi.org/10.1007/s10956015-9597-x

Diego Obregón, R. (2014). Realidad Aumentada en documentos e imágenes. Revista Aula de Innovación Educativa, 230, 65-66.

Dunleavy, M., \& Dede, C. (2014). Augmented Reality Teaching and Learning. In J. M. Spector, M. D. Merrill, J. Elen, \& M. J. Bishop (Eds.), Handbook of Research on Educational Communications and Technology (pp. 735-745). Springer New York. https://doi.org/10.1007/978-1-4614-3185-5_59

Elhoushi, M., Georgy, J., Noureldin, A., \& Korenberg, M. J. (2016). Motion Mode Recognition for Indoor Pedestrian Navigation Using Portable Devices. IEEE Transactions on Instrumentation and Measurement, 65(1), 208-221. https://doi.org/10.1109/TIM.2015.2477159

Favier, T. T., \& van der Schee, J. A. (2012). Exploring the characteristics of an optimal design for inquirybased geography education with Geographic Information Systems. Computers \& Education, 58(1), 666677. https://doi.org/10.1016/j.compedu.2011.09.007 
Joo-Nagata, J., Martínez Abad, F., García-Bermejo Giner, J., \& García-Peñalvo, F. J. (2017). Augmented reality and pedestrian navigation through its implementation in m-learning and e-learning: Evaluation of an educational program in Chile. Computers \& Education, 111, 1-17. doi:10.1016/j.compedu.2017.04.003

Fino, E. R., Martín-Gutiérrez, J., Fernández, M. D. M., \& Davara, E. A. (2013). Interactive tourist guide: Connecting web 2.0, augmented reality and QR codes (Vol. 25, pp. 338-344). Presented at the Procedia Computer Science. https://doi.org/10.1016/j.procs.2013.11.040

FitzGerald, E., Adams, A., Ferguson, R., Gaved, M., Mor, Y., \& Thomas, R. (2012). Augmented reality and mobile learning: the state of the art. In CEUR Workshop Proceedings (Vol. 955, pp. 62-69). Helsinki, Finland. Retrieved from http://ceur-ws.org/Vol-955/papers/paper 49.pdf

Friess, D. A., Oliver, G. J. H., Quak, M. S. Y., \& Lau, A. Y. A. (2016). Incorporating 'virtual' and 'real world' field trips into introductory geography modules. Journal of Geography in Higher Education, $0(0)$, 1-19. https://doi.org/10.1080/03098265.2016.1174818

Furió, D., Juan, M.-C., Seguí, I., \& Vivó, R. (2014). Mobile learning vs. traditional classroom lessons: a comparative study. Journal of Computer Assisted Learning, 189-201. https://doi.org/10.1111/jcal.12071

García Holgado, A., García Peñalvo, F., Zangrando, V., \& Seoane Pardo, A. M. (2013). Learning Object Model and Framework Design for the Digital Modules Production. In F. García Peñalvo (Ed.), Multiculturalism in Technology-Based Education: Case Studies on ICT-Supported Approachesc (pp. 2836). United States: Information Science Reference. https://doi.org/10.4018/978-1-4666-2101-5.ch003 Gardner, H. (2006). Multiple Intelligences: New Horizons. New York: Basic Books.

Graham, M., Zook, M., \& Boulton, A. (2013). Augmented reality in urban places: contested content and the duplicity of code. Transactions of the Institute of British Geographers, 38(3), 464-479. https://doi.org/10.1111/j.1475-5661.2012.00539.x

Grissom, R. J., \& Kim, J. J. (2011). Effect sizes for research: univariate and multivariate applications. (2nd ed.). Routledge.

Hernández, R., Fernández, C., \& Baptista, P. (2010). Metodología de la investigación (5th ed.). México: McGraw Hill.

Huang, C. S. J., Yang, S. J. H., Chiang, T. H. C., \& Su, A. Y. S. (2016). Effects of Situated Mobile Learning Approach on Learning Motivation and Performance of EFL Students. Journal of Educational Technology \& Society, 19(1), 263-276.

Huang, W., Sun, M., \& Li, S. (2016). A 3D GIS-based interactive registration mechanism for outdoor augmented reality system. Expert Systems with Applications, 55, 48-58. https://doi.org/10.1016/j.eswa.2016.01.037

Huang, Y.-M., Chiu, P.-S., Liu, T.-C., \& Chen, T.-S. (2011). The design and implementation of a meaningful learning-based evaluation method for ubiquitous learning. Computers \& Education, 57(4), 2291-2302. https://doi.org/10.1016/j.compedu.2011.05.023

Jamali, S. S., Shiratuddin, M. F., \& Wong, K. W. (2014). A review of augmented reality (AR) and mobileaugmented reality (mAR) technology: Learning in tertiary education. International Journal of Learning in Higher Education, 20(2), 37-54.

Kamarainen, A. M., Metcalf, S., Grotzer, T., Browne, A., Mazzuca, D., Tutwiler, M. S., \& Dede, C. (2013). EcoMOBILE: Integrating augmented reality and probeware with environmental education field trips. Computers \& Education, 68, 545-556. https://doi.org/10.1016/j.compedu.2013.02.018

Kim, H., \& Han, S. (2014). A Framework for the Automatic 3D City Modeling using the Panoramic Image from Mobile Mapping System and Digital Maps. 2014 Ieee Virtual Reality (vr), 133-134.

Kvale, S. (2007). Doing interviews. London: SAGE Publications.

Loewnthal, K. M. (1996). An introduction to psychological tests and scales. Londres: UCL Press.

Martín Gutiérrez, J., \& Meneses Fernández, M. (2014). Applying Augmented Reality in Engineering Education to Improve Academic Performance \& Student Motivation. International Journal of Engineering Education, 30(3), 1-11.

Martín Izard, J. F. (2011). Técnicas de encuesta: cuestionario y entrevista. In S. Nieto Martín (Ed.), Principios, métodos y técnicas esenciales para la investigación educativa (1st ed., pp. 145-168). Madrid: Dykinson, S.L. Retrieved from http://books.google.es/books?id=jJrFZwEACAAJ

Martínez, A. M., Navarro, J. G. C., \& Sánchez, J. A. R. (2012). Aprendizaje basado en competencias: Una propuesta para la autoevaluación del docente. Profesorado. Revista de Currículum y Formación de Profesorado, 16(2), 325-338.

Martínez Abad, F. (2013). Evaluación y Formación en Competencias Informacionales en la Educación Secundaria Obligatoria. Universidad de Salamanca, Salamanca, España. Retrieved from http://www.europeana.eu/portal/record/2022701/oai_gredos_usal_es_10366_121869.html

Martínez Clares, P., \& Echeverría Samanes, B. (2009). Formación basada en competencias. Revista de Investigación Educativa, 27(1), 125-147.

Martinez-Grana, A. M., Goy, J. L., \& Cimarra, C. A. (2013). A virtual tour of geological heritage: Valourising geodiversity using Google Earth and QR code. Computers \& Geosciences, 61, 83-93. https://doi.org/10.1016/j.cageo.2013.07.020

Mathias, M., \& Gallagher, J. (2015). Swift Programming: The Big Nerd Ranch Guide. Estados Unidos: Big 
Joo-Nagata, J., Martínez Abad, F., García-Bermejo Giner, J., \& García-Peñalvo, F. J. (2017). Augmented reality and pedestrian navigation through its implementation in m-learning and e-learning: Evaluation of an educational program in Chile. Computers \& Education, 111, 1-17. doi:10.1016/j.compedu.2017.04.003

Nerd Ranch Guides.

Mayer, R. E. (2009). Multimedia Learning (2nd ed.). Cambridge: Cambridge University Press.

Mayr, S., Buchner, A., Erdfelder, E., \& Faul, F. (2007). A short tutorial of GPower. Tutorials in Quantitative Methods for Psychology, 3(2), 51-59.

Ministerio de Educación Chile. (2015, August 21). Estadísticas de la Educación 2014. MINEDUC. Retrieved from http://centroestudios.mineduc.cl/index.php? $\mathrm{t}=96 \& \mathrm{i}=2 \& \mathrm{cc}=2036 \& \mathrm{tm}=2$

Muñiz, J. (2010). Las teorías de los tests: Teoría Clásica y Teoría de Respuesta a los Ítems. Papeles del Psicólogo, 31(1), 57-66.

Muñoz Cristóbal, J. A., Martínez Monés, A., Asensio Pérez, J. I., Villagrá Sobrino, S. L., Hoyos Torio, J. E., \& Dimitriadis, Y. (2014). City Ads: Embedding Virtual Worlds and Augmented Reality in Everyday Educational Practice. Journal of Universal Computer Science, 20(12), 1670-1689.

Newcombe, N. S., \& Frick, A. (2010). Early education for spatial intelligence: Why, what, and how. Mind, Brain, and Education, 4(3), 102-111.

Nieto Martín, S. (2011). Medidas de tendencia central y variabilidad. In S. Nieto Martín (Ed.), Principios, métodos y técnicas esenciales para la investigación educativa (1st ed., pp. 145-168). Madrid: Dykinson, S.L. Retrieved from http://books.google.es/books?id=jJrFZwEACAAJ

Nunnally, J. C. (1978). Psychometric theory (2nd ed.). New York: McGraw-Hill.

Pardo Merino, A. (2002). SPSS 11: guía para el análisis de datos. España: McGraw-Hill.

Pendit, U. C., Zaibon, S. B., \& Abubakar, J. A. (2015). Digital interpretive media usage in cultural heritage sites at yogyakarta. Jurnal Teknologi, 75(4), 71-77.

Ramirez, V., \& Cassinerio, S. (2014). Realidad Aumentada-trabajo cooperativo; Nivel Inicial. (pp. 1-21). Presented at the Congreso Iberoamericano de Ciencia, Tecnología, Innovación y Educación, Buenos Aires. Retrieved from http://www.oei.es/congreso2014/memoriactei/1669.pdf

Rehman, U., \& Cao, S. (2017). Augmented-Reality-Based Indoor Navigation: A Comparative Analysis of Handheld Devices Versus Google Glass. Ieee Transactions on Human-Machine Systems, 47(1), 140-151. https://doi.org/10.1109/THMS.2016.2620106

Reinoso, R. (2012). Posibilidad de la Realidad Aumentada en Educación. In J. Hernández, D. Pennesi, D. Sobrino, \& A. Vázquez (Eds.), Tendencias emergentes en Educación con TIC (pp. 175-196). Barcelona: Espiral.

Rodríguez Conde, M. J. (2011). Test y otras pruebas escritas u orales. In S. Nieto Martín (Ed.), Principios, métodos y técnicas esenciales para la investigación educativa (1st ed., pp. 191-219). Madrid: Editorial Dykinson, S.L. Retrieved from http://books.google.es/books?id=jJrFZwEACAAJ

Sánchez Prieto, J. C., Olmos Migueláñez, S., \& García Peñalvo, F. (2013). Mobile Learning: Tendencies and Lines of Research. In Proceedings of the First International Conference on Technological Ecosystem for Enhancing Multiculturality (pp. 473-480). New York, NY, USA: ACM. https://doi.org/10.1145/2536536.2536609

Sánchez Prieto, J. C., Olmos Migueláñez, S., \& García Peñalvo, F. (2016). Informal tools in formal contexts: Development of a model to assess the acceptance of mobile technologies among teachers. Computers in Human Behavior, 55, Part A, 519-528. https://doi.org/10.1016/j.chb.2015.07.002

Satpute, T., Pingale, S., \& Chavan, V. (2015). Augmented reality in e-learning review of prototype designs for usability evaluation. In 2015 International Conference on Communication, Information Computing Technology (ICCICT) (pp. 1-4). https://doi.org/10.1109/ICCICT.2015.7045712

Sommerauer, P., \& Müller, O. (2014). Augmented reality in informal learning environments: A field experiment in a mathematics exhibition. Computers \& Education, 79, 59-68. https://doi.org/10.1016/j.compedu.2014.07.013

Teddlie, C., \& Yu, F. (2007). Mixed Methods Sampling A Typology With Examples. Journal of Mixed Methods Research, 1(1), 77-100. https://doi.org/10.1177/2345678906292430

Van Schaik, L. (2008). Spatial Intelligence: New Futures for Architecture. West Sussex: Wiley. Retrieved from http://eu.wiley.com/WileyCDA/WileyTitle/productCd-047072322X.html

Vela Peón, F. (2001). Un acto metodológico básico de la investigación social: la entrevista cualitativa. In M. L. Tarrés (Ed.), Observar, escuchar y comprender sobre la tradición cualitativa en la investigación social (pp. 63-94). México: El colegio de México, FLACSO.

Wei, X., Weng, D., Liu, Y., \& Wang, Y. (2015). Teaching based on augmented reality for a technical creative design course. Computers \& Education, 81, 221-234. https://doi.org/10.1016/j.compedu.2014.10.017

Yang, L. (2013). El Concepto y el Proceso de Apropiación de una Tecnología Móvil aplicada a la Práctica a la Práctica Formativa: Estudio de Caso en el CEO Miguel Delibes en Salamanca. Universidad de Salamanca, Salamanca. 